\title{
Signs of Power: Talismanic Writing in Chinese Buddhism
}

\section{Citation}

Robson, James. 2008. Signs of power: talismanic writing in Chinese Buddhism. History of Religions 48(2): 130-169.

\section{Permanent link}

http://nrs.harvard.edu/urn-3:HUL.InstRepos:11315419

\section{Terms of Use}

This article was downloaded from Harvard University's DASH repository, and is made available under the terms and conditions applicable to Other Posted Material, as set forth at http:// nrs.harvard.edu/urn-3:HUL.InstRepos:dash.current.terms-of-use\#LAA

\section{Share Your Story}

The Harvard community has made this article openly available.

Please share how this access benefits you. Submit a story.

Accessibility 


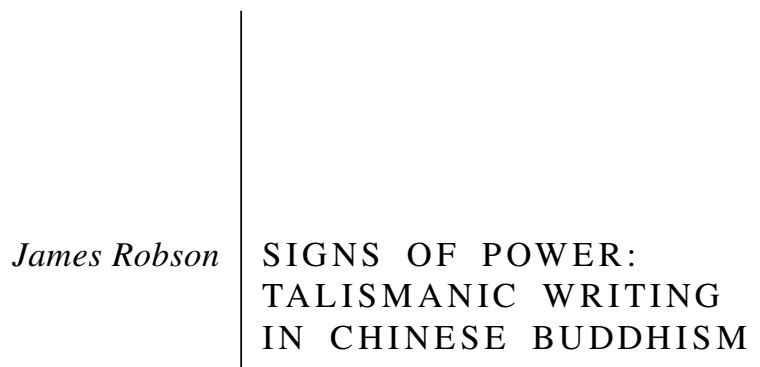

Throughout much of the ancient world talismans or amulets written in an esoteric script were worn or ingested in order to repel the demonic and impel the desired. ${ }^{1}$ Talismans and other objects—-such as bowls or pieces of metal-emblazoned with either legible or illegible talismanic script are well known to scholars of the ancient Mediterranean world. It is unclear, however, precisely when tablets with writing that is backwards, scrambled, or otherwise unintelligible began to appear in the ancient world, but by

Much of the research reflected in this article was initially presented at the "Tantra and Daoism" conference at Boston University in 2002, at the International Association of Buddhist Studies meeting in Thailand in 2002, at McMaster University in 2003, at the "Manipulating Magic: Sages, Sorcerers and Scholars" conference at Yale University in 2005, and at the "Knowledge and Belief" symposium at the Stanford University Humanities Center in 2005. I would like to thank all of the commentators and participants in those events for their critical feedback and suggestions.

${ }^{1}$ There is an increasingly large body of material on these topics, but see, among others, Theodor H. Gaster, "Amulets and Talismans," in Hidden Truths: Magic Alchemy and the Occult, ed. Lawrence E. Sullivan (New York: Macmillan, 1987), 145-47; and Don C. Skemer, Binding Words: Textual Amulets in the Middle Ages (University Park: Pennsylvania State University Press, 2006). On the comparative context of using esoteric script as medium for communication with the realm of spirits, see John G. Gager, ed., Curse Tablets and Binding Spells from the Ancient World (Oxford: Oxford University Press, 1992), 9-10; Christopher A. Faraone and Dirk Obbink, eds., Magika Hiera: Ancient Greek Magic and Religion (Oxford: - Oxford University Press, 1991); and Stanley J. Tambiah, "The Magical Power of Words," Man 3 (1968): 177-206. 
the late Roman period (fourth to fifth century CE) a mystical form of writing is attested on defixiones - curse tablets and binding spells. ${ }^{2}$ Amulets and incantation bowls with magical characters or signs appear with regularity in Jewish magic and are found in "Palestinian amulets, Samaritan amulets, and European Jewish magical texts, and they have found their way into Christian magical handbooks as well." ${ }^{3}$ Within the Islamic tradition prayer bowls are inscribed with Qur'anic verses that empower the water that is poured into the bowls and imbibed by the sick. There are also Islamic divination bowls, and talismanic shirts and mirrors that have esoteric diagrams composed of numbers, letters, and "illegible signs."

Texts and objects that include an esoteric or illegible form of writing are also found in East Asia, where they have been employed in a variety of religious contexts, including within Daoism, popular religion, and-despite much writing to the contrary-within Buddhism. Indeed, there is a large corpus of Buddhist manuscripts in which, like the Greek magical papyri discussed by Jonathan Z. Smith, "the chief ritual activity . . appears to be the act of writing itself. Alongside the evident concern for the accurate transmission of a professional literature marked, among other features, by scribal glosses and annotations, is an overwhelming belief in the efficacy of writing, especially in the recipes that focus on the fashioning of amulets and phylacteries." ${ }^{5}$ Whereas talismans in the Greek and other contexts of the ancient world have received significant scholarly attention, it is to an oft overlooked collection of Buddhist talismans that are empowered by a form of writing that appears illegible-what Bronislaw Malinowski referred to as having a "coefficient of weirdness" in the context of Trobriand Island word magic — that I want to direct my thoughts in the words that follow. ${ }^{6}$

\footnotetext{
${ }^{2}$ Gager, Curse Tablets and Binding Spells from the Ancient World; and Christopher A. Faraone, "The Agonistic Context of Early Greek Binding Spells," in Farraone and Obbink, Magika Hiera: Ancient Greek Magic and Religion, 6.

${ }^{3}$ Lawrence H. Schiffman and Michael D. Swartz, Hebrew and Aramaic Incantation Texts from the Cairo Genizah: Selected Texts from Taylor-Schechter Box K1 (Sheffield: JSOT Press, 1992), 44. See also the two volumes by Joseph Naveh and Shaul Shaked entitled Amulets and Magic Bowls: Aramaic Incantations of Late Antiquity (Jerusalem: Magnes Press, 1985) and Magic Spells and Formulae: Aramaic Incantations of Late Antiquity (Jerusalem: Magnes Press, 1993).

${ }^{4}$ Ülkü Bates, "The Use of Calligraphy on Three Dimensional Objects: The Case of 'Magic' Prayer Bowls," in Brocade of the Pen: The Art of Islamic Writing, ed. Carol Garrett Fisher (East Lansing: Michigan State University, 1991), 55-61.

5 Jonathan Z. Smith, "Trading Places," in Relating Religion: Essays in the Study of Religion (Chicago: University of Chicago Press, 2004), 226. See also David Frankfurter, "The Magic of Writing and the Writing of Magic: The Power of the Word in Egyptian and Greek Traditions," Helios 21 (1994): 179-221.

${ }^{6}$ See the sections entitled "The Meaning of Meaningless Words" and "Coefficient of Weirdness in the Language of Magic," in Bronislaw Malinowski, Malinowski Collected Works, vol. 8, Coral Gardens and Their Magic (London: Routledge, 2002), 213-23. Stanley Tambiah has also considered how in Sinhalese ritual a kind of sacred oral language is often
} 
While doing fieldwork in China some years ago, I entered a shrine located on the summit of a mountain and saw that there was a small wooden table that had a candle and various writing implements. When I had earlier visited the same site, a Daoist priest was sitting at the table writing and selling talismans to long lines of devotees. On a more recent visit, however, I saw that the same table was now staffed by a Buddhist monk writing out the same talismans for an equally long line of pilgrims. Those talismans (on red or yellow paper with black or red writing) are thought to provide practical benefits like "knowledge and wisdom" (congming zhihui 聰明智慧), “elevation of status and rank" (luwei gaosheng 祿位高升), and “success in school” (xueye chengjiu 學業成就). The style and function of those talismans are similar to the style and function of present-day talismans available for purchase at other sites in China, at temples and shrines throughout Japan (such as ofuda お札 or omamori お守り), and even in Chinese diaspora communities in Thailand and Malaysia. $^{7}$

At first sight, the scene of a Buddhist monk writing what looked like popular or Daoist talismans was striking and raised a number of questions. Was there historical precedent for Buddhists writing and employing talismans? Resisting the temptation to explain away this practice as merely a form of contemporary Chinese popular religiosity that tends to mix and match various elements of Buddhism, Daoism, and Confucianism, what some have decried as a form of "degenerative syncretism," I instead de-

employed rather than normal everyday language and that the sacred language was usually perceived as efficacious and powerful due to the fact that it was incomprehensible. See Tambiah, "The Magical Power of Words," 177-206. There was also a written counterpart to the types of magical properties of words that Tambiah discusses. John Gager and others have shown the ubiquity of the use of an esoteric script that is found in ancient Greece and Rome, and Antoine Faivre has also noted the "liking on the part of many esotericists for 'secret writing,'" such as that of the sixteenth-century figure Johannes Trithemius, who was noted for his famous steganographia. See Gager, Curse Tablets and Binding Spells from the Ancient World; and Antoine Faivre, "The Notions of Concealment and Secrecy in Modern Esoteric Currents since the Renaissance (a Methodological Approach)," in Rending the Veil: Concealment and Secrecy in the History of Religions, ed. Elliot R. Wolfson (New York: Seven Bridges Press, 1999), 155-76. On Johannes Thrithemius, see Noel L. Brann, The Abbot Trithemius (14621516) (Leiden: Brill, 1981), and Trithemius and Magical Theology: A Chapter in the Controversy over Occult Studies in Early Modern Europe (Albany: SUNY Press, 1999).

7 On talismans and their relation to "worldly benefits" (genze riyaku) in Japan; see Ian Reader and George J. Tanabe Jr., Practically Religious: Worldly Benefits and the Common Religion of Japan (Honolulu: University of Hawaii Press, 1998). For a comprehensive survey of esoteric talismans in Asia, see Ogata Tōru 大形徹, Sakade Yoshinobu 坂出祥伸, and Yoritomi Motohiro 頼富本宏, eds., Dōkyō teki mikkyō teki hekija jubutsu no chōsa kenkyū 道教的密教的辟邪呪物の調查・研究 (Tokyo: Biingu Netto Puresu, 2005); and the work on spells and talismans by Sawada Mizuho 澤田瑞穂 entitled Chūgoku no juhō 中国の呪法 (Tokyo: Hirakawa shuppansha, 1984). On the popular role of Chinese charms and talismans in contemporary Singapore and Malaysia, see Marjorie Topley, "Paper Charms, and Prayer Sheets as Adjuncts to Chinese Worship," Journal of the Malayan Branch of the Royal Asiatic Society 26 (1953): 63-84. 
cided to turn to the medieval Chinese historical record to see what could be found. One of the goals of tracing the historical background of those talismanic practices was to take seriously the late Michel Strickmann's comments on the need to combine anthropological/ethnographic observation of contemporary practices with a historical perspective grounded in medieval Chinese primary sources. ${ }^{8}$

While the winding textual path that I began to follow eventually led to a corpus of medieval Buddhist sources, it was not a particularly wellmarked trail, and it seemed that all the signs (that is to say, scholarship on Chinese Buddhism) were pointing in the wrong directions. Simply put, talismans and texts that include talismanic script have heretofore remained all but invisible to scholars of Chinese Buddhism since they have traditionally understood them to be of a Daoist provenance and have tended to place them on the wrong side of the problematic Western division between "pure" religion and "denigrated" magic. ${ }^{9}$ As is now well known, between those polemical terms, it is magic that "has been made to play the role of an evaluative rather than an interpretive term and, as such, usually bears a negative valence." 10 Therefore, anything labeled as magic, and particularly a material object like a talisman that bears too close of a connection to a fetish, is discarded posthaste. ${ }^{11}$

These interpretive problems are related in part to the now well-known "Protestant" assumptions that characterized early Buddhist studies and

\footnotetext{
${ }^{8}$ See Michel Strickmann, "Homa in East Asia," in Agni: The Vedic Ritual of the Fire Altar, ed. Frits Staal (Berkeley: University of California Press, 1982), 420-21.

${ }^{9}$ There is a larger body of literature on this problematic divide. See, among others, Randall Styers, Making Magic: Religion, Magic, and Science in the Modern World (Oxford: Oxford University Press, 2004); Smith, "Trading Places"; Hildred Geertz, "An Anthropology of Religion and Magic. I," Journal of Interdisciplinary History 8 (1975): 71-89; Dorothy Hammond, "Magic: A Problem in Semantics," American Anthropologist 72, no. 6 (1970): 1349-56; John Skorupski, Symbol and Theory: A Philosophical Study of Theories of Religion in Social Anthropology (Cambridge: Cambridge University Press, 1976); Gustavo Benavides, "Magic, Religion, Materiality," Historical Reflections/Refexiones Historiques 23, no. 3 (1997): 301-30; and Michael Brown, "Thinking about Magic," in Anthropology of Religion: A Handbook, ed. Stephen D. Glazier (Westport, CT: Greenwood, 1997). Attempts to redress the problematic relationship between religion and magic in East Asia include Michel Strickmann, Chinese Magical Medicine, ed. Bernard Faure (Stanford, CA: Stanford University Press, 2002); Donald Harper, Early Chinese Medical Literature: The Mawangdui Medical

Manuscripts (London: Kegan Paul International, 1998); and most recently Robert Ford Campany, "Secrecy and Display in the Quest for Transcendence in China, ca. 220 BCE-350 CE," History of Religions 45, no. 4 (2006): 291-336. For this problem in relation to Tantric studies, see David L. Snellgrove, Indo-Tibetan Buddhism (Boston: Shambala, 1987), 143; and Stephan Beyer, The Cult of Tārā: Magic and Ritual in Tibet (Berkeley: University of California Press, 1973).

${ }^{10}$ Smith, "Trading Places," 218.

11 On the discomfort with the fetish and fetishism, see Tomoko Masuzawa, "Troubles with Materiality: The Ghost of Fetishism in the Nineteenth Century," Comparative Studies in Society and History 42, no. 2 (April 2000): 242-66.
} 
have yet to be overcome entirely. ${ }^{12}$ Colonel Henry Steel Olcott (18321907), the cofounder of the Theosophical Society and a late nineteenthcentury Western commentator on - and propagator of - a particular view of Buddhism, explained the alleged inappropriateness of the use of talismans within Buddhism by writing: "Question: Are charms, incantations, the observance of lucky hours and devil dancing a part of Buddhism? Answer: They are positively repugnant to its fundamental principles. They are surviving relics of fetishism and pantheistic and other foreign religions." 13 Despite the insistence on the primacy of "pure beliefs," and the ironic fact that Colonel Olcott later became known for effecting cures through his knowledge of mesmerism, this view can be seen as representative (though clearly from one extreme) of more widely held assumptions about the role (or lack thereof) of talismans or charms in Buddhism. ${ }^{14}$ The entry on amulets and talismans in J. Z. Smith's Dictionary of Religion includes a subheading on talismans in Chinese religion that reflects more recent general knowledge. The entry reads: "Amulets and talismans are used in Taoism and in folk practices primarily for healing and protection, especially the protection of young children. They may be stamped with a seal or written out by hand on paper with the appropriate color ink by a Taoist priest or other professional. Most talismans display divinatory diagrams and a highly stylized script understood to be heavenly writing. Talismans are usually burned and the ashes ingested or scattered, but they may also be worn on one's person or mounted on a wall." 15 This is a succinct and unproblematic entry as far as it goes, but it is notable that this entry only mentions Daoist and folk use of talismans and mentions nothing about their use within Buddhism.

It is not only modern Western scholars that have emphasized the exclusive Daoist use of talismans and depicted Buddhists as being categorically opposed to them. This same perspective is found in standard contemporary Japanese-language Buddhist reference works. It is noteworthy, for example, that Mochizuki Shinkō 望月信亨 does not include an entry on talismans in his encyclopedic Bukkyo daijiten 佛教大辭典

\footnotetext{
12 See, among others, Gregory Schopen, "Archaeology and Protestant Presuppositions in the Study of Indian Buddhism," History of Religions 31 (1991): 1-23.

${ }^{13}$ Henry Steel Olcott, The Buddhist Catechism (Madras: Theosophical Publishing House, 1947; first published in 1881), 44-45.

14 On Henry Steel Olcott, see Stephen Prothero, The White Buddhist: The Asian Odyssey of Henry Steel Olcott (Bloomington: Indiana University Press, 1996); and Donald S. Lopez Jr., "Belief," in Critical Terms for Religious Studies, ed. Mark C. Taylor (Chicago: University of Chicago Press, 1998), 29-32.

15 Jonathan Z. Smith, ed., The HarperCollins Dictionary of Religion (San Francisco: Harper San Francisco, 1995), 45.
} 
(Great dictionary of Buddhism). ${ }^{16}$ Nakamura Hajime's 中村元 Bukkyo go daijiten 佛教語大辞典 (Great dictionary of Buddhist terminology) includes the following entry on "talismanic writing" ( fushu 符書, Jpn. fushō) that speaks for itself: "Talismanic writing: An expression regarding the writing (drawing) of a talisman, related to amulets (talismans). Since [these talismans] are connected to magic (sorcery) they are excluded from Buddhism [符書] 符に書いた文句, 護符のことか, 呪術に関係 があるので，佛教では排斥された.”17 Thus, a kind of exorcism has been performed on precisely those objects within the Buddhist tradition that threaten to make it appear too magical. That these writers felt the need to repress the use of these objects further suggests that Buddhists in China partook of a wide range of occult practices and employed an arsenal of techniques to repel the harmful and impel the desired.

\section{IN OTHER WORDS: TALISMANIC WRITING}

There is an extensive literature on the history and function of Chinese talismans within the pre-Daoist and Daoist contexts. ${ }^{18}$ Given that information on the use of talismans in Daoism is readily available, I will limit my comments to just the barest of outlines. Pioneering early French sinologists like Max Kaltenmark, Robert des Rotours, and others have detailed how the original meaning of the character for "tally" ( $f u$ 符), referred to two halves of an object, usually in the shape of a dragon, fish, or tiger that were

\footnotetext{
${ }^{16}$ Mochizuki Shinkō 望月信亨, ed., Bukkyō daijiten 仏教大辞典, rev. and enlarged ed., 10 vols. (Tokyo: Sekai Seiten Kankō Kyōkai, 1958-63).

${ }^{17}$ Nakamura Hajime 中村元, Bukkyō go daijiten 佛教語大辞典 (Tokyo: Tokyo shoseki, 1975), 1178a-b.

${ }^{18}$ See the comprehensive study and review of recent work on talismans and diagrams in Catherine Despeux, "Talismans and Diagrams," in Daoism Handbook, ed. Livia Kohn (Leiden: Brill, 2000), 498-540. The authoritative work on talismans in Chinese Dunhuang manuscripts is now Christine Mollier, "Talismans," in Divination et société dans la Chine médiévale: Étude des manuscrits de Dunhuang de la Bibliothèque nationale de France et de la British Library, ed. Marc Kalinowski (Paris: Bibliothèque nationale de France, 2003), 405-29. See also, among others, Isabelle Robinet, Taoist Meditation: The Mao-shan Tradition of Great Purity (Albany: SUNY Press, 1993), 31ff.; Lothar Ledderose, "Some Taoist Elements in the Calligraphy of the Six Dynasties," T'oung Pao 70 (1984): 246-78; and Jonathan Chaves, “The Legacy of Ts' ang Chieh: The Written Word as Magic," Oriental Art 23, no. 2 (Summer 1977): 200-215. There is also an important series of articles by Wang Yucheng 王育成 that includes "Lüelun kaogu faxian de zaoqi daofu” 略論考古發現的早期道符, Kaogu 考古 1 (1998): 75-81, “Dong Han daofu shili” 東漢道符釋例, Kaogu xuebao 考古學報 1 (1991): 45-56, and “Tang Song daojiao mizhuanwen shili” 唐宋道教秘管文釋例, Zhongguo lishi bowuguan guankan 中國歷史博物館館刊(1991): 82-93. For possible antecedents to talismanic script, see Tseng Yuho, A History of Chinese Calligraphy (Hong Kong: Chinese University Press, 1993), 75ff. and the work on "bird script" by Rong Geng 容庚, "Niaoshu kao" 鳥書考, Yanjing xuebao 燕京學報, no. 16 (1934): 195-203, “Niaoshu kao buzheng”鳥書考 補正, Yanjing xuebao 燕京學報, no. 17 (1935): 173-78, “Niaoshu san kao” 鳥書三考, and Yanjing xuebao 燕京學報, no. 23 (1938): 287-89.
} 
split down the middle and inscribed on the back. Each of two contracting parties would keep one half as a guarantee of an agreement. ${ }^{19}$ Some twenty years ago, Anna Seidel emphasized that talismans were not invented by nor the sole prerogative of Daoists, but rather they emerged out of Han dynasty imperial treasure objects. ${ }^{20}$ One of the early functions of the talisman was for a ruler to authorize the conduct and scope of authority of a general (e.g., how many troops he could command). ${ }^{21}$ The military context of talismans later found a corollary in the spiritual realm and permitted their possessor to summon and control a variety of deities that could be drawn on in battles with spirits. ${ }^{22}$ Talismans written in an esoteric script are also found on Han tomb objects (see fig. 1), where they "figure at the end of several ordinance and contract texts. They also occur separately or combined with short demon-subduing spells on wooden tablets or on jars." ${ }^{23}$ Based on the available evidence, the earliest uses of talismans were for healing, exorcism, and protection. What was it about the esoteric script on these talismans that imbued them with such powers?

As many scholars of Chinese script have noted, it was believed that the earliest forms of writing in China were not used to transcribe human speech but, rather, preceded it and were signs that reflected the hidden powers of the universe and were used to "communicate with the spirits." ${ }^{4}$ Léon

${ }^{19}$ Max Kaltenmark, "Ling-pao: Note sur un terme du taoisme religieux," in Mélanges publies par l'Institut des Hautes Études Chinoises (Paris, 1960), 1:559-88; and Robert des Rotours, "Les insignes en deux parties (fou) sous la dynastie des T'ang (618-907)," T'oung Pao 41 (1952): 1-148. See also the discussions in John Lagerwey, Taoist Ritual in Chinese Society and History (New York: Macmillan, 1987), 149-67.

${ }^{20}$ Anna Seidel, "Imperial Treasures and Taoist Sacraments: Taoist Roots in the Apocrypha," in Tantric and Taoist Studies, vol. 2, ed. M. Strickmann (Bruxelles: Institut Belge des Hautes Études Chinoises, 1983), 292.

${ }^{21}$ Mark Edward Lewis, Writing and Authority in Early China (Albany: SUNY Press, 1999), 29; and Seidel, "Imperial Treasures and Taoist Sacraments," 310.

${ }^{22}$ Seidel, "Imperial Treasures and Taoist Sacraments," 315.

${ }^{23}$ Anna Seidel, "Traces of Han Religion in Funeral Texts Found in Tombs," in Dōkyō to shūkyō bunka, ed. Akitsuki Kan'ei 秋月觀暎 (Tokyo: Hirakawa, 1987), 27.

${ }^{24}$ See John Lagerwey, "The Oral and Written in Chinese and Western Religion," in Religion und Philosophie in Ostasien: Festschrift für Hans Steininger, ed. Gert Naundorf, Karl-Heinz Pohl, and Hans-Hermann Schmidt (Würzburg: Königshausen \& Neumann, 1985), 301-21, and his comments on the foundational work of Léon Vandermeersch, Wangdao ou la voie royale: Recherches sur l'esprit des institutions de la Chine archaique, vol. 2, Structures politiques, les rites (Paris: Publications de l'Ecole Française d'Extrême-Orient, 1980). See also the section titled "China's Graphic Language," in Anna Seidel, "Chronicle of Taoist Studies," Cahiers d'Extrême-Asie 5 (1990): 223-347; Kristofer M. Schipper, "The Written Memorial in Taoist Ceremonies," in Religion in Chinese Society, ed. Arthur Wolf (Stanford, CA: Stanford University Press, 1974), 324; and T. H. Hsien, Written on Bamboo and Silk: The Beginnings of Chinese Books and Inscriptions (Chicago: University of Chicago Press, 1962). The characteristics of writing discussed here were not specific to China; see Henri-Jean Martin, The History and Power of Writing (Chicago: University of Chicago Press, 1994), 4. It should be pointed out here, however, that this view of the origins of Chinese script as preceding the oral is not a return to the fallacious view of early Chinese script as ideographic. See William 

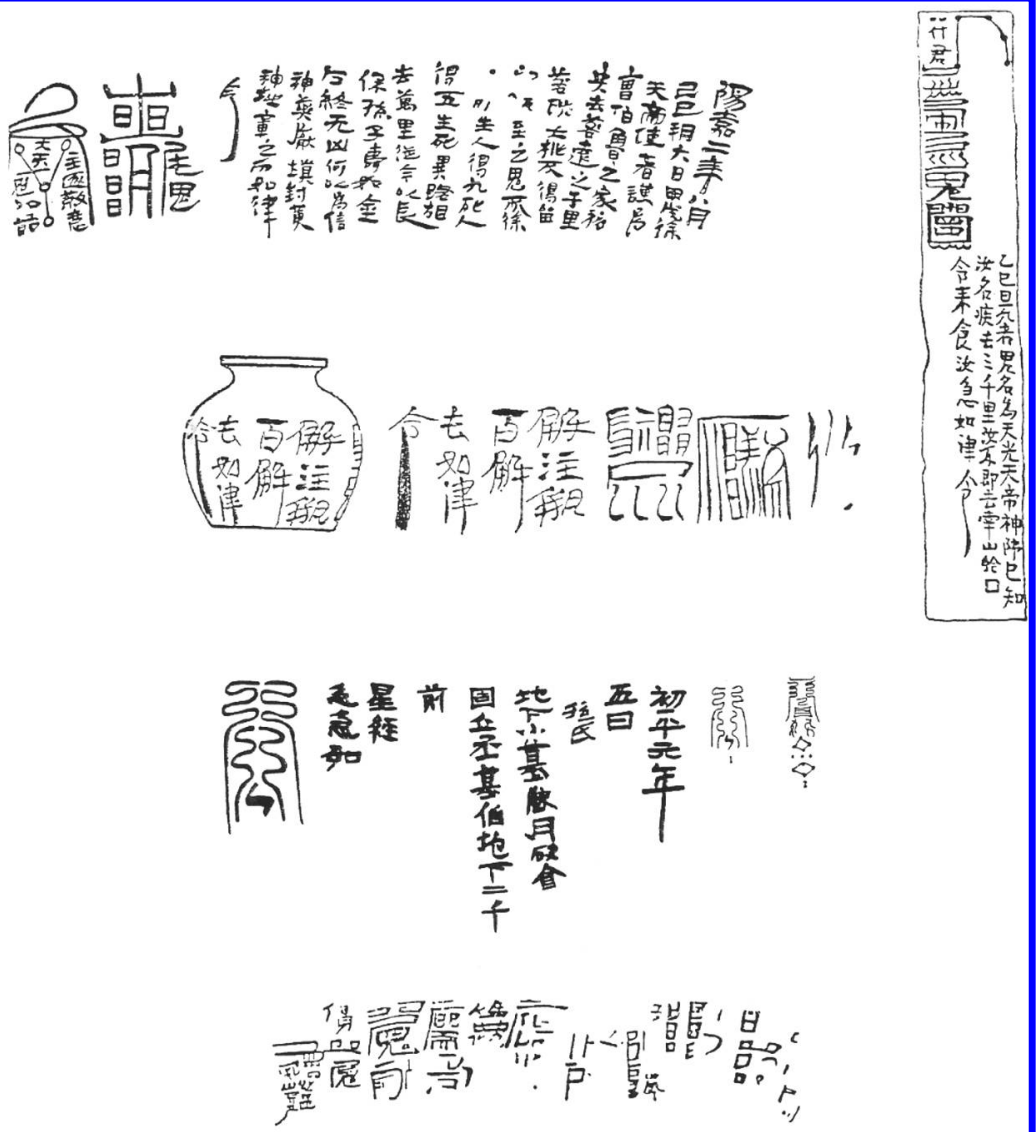

FIG. 1.-Samples of talismans found on funerary jars and wooden slips in Han tombs. Sources: The talismans are reproduced from Wang Yucheng 王育成, “Dong Han daofu shili 東漢道符釋例," Kaogu xuebao 考古學報 1 (1991): 4556, 46 (top two on left side); Gao Dalun 高大倫 and Jia Maiming 賈麥明, “Han chuping yuannian zhushu zhenmu taoping 漢初平元年朱書鎮墓陶瓶, ” in Wenwu 文物 6 (1987): 72 (left side third from top); Wang Yucheng, "Lüelun kaogu faxian de zaoqi daofu 略論考古發現的早期道符," Kaogu 考古 1 (1998): 75-81, 77 and 78 (bottom left and right side).

Vandermeersch has suggested that "the most archaic prototypes of the Chinese characters must have been emblematic monograms of spiritual

G. Boltz, The Origin and Early Development of the Chinese Writing System (New Haven, CT: American Oriental Society, 2003). 
protectors," and "must have been simply talismanic, that is, composed of juxtaposed or imbricated graphs without any articulation of a linguistic nature." 25 Since written traces were at root "patterns" (wen 文) originating in nature they controlled what they represented through their potent spiritual power. ${ }^{26}$ This background is fundamental to understanding a passage in the Huainanzi 淮南子 that says, for example, "Of old when Cangjie originated writing, Heaven rained down grain and the demons howled at night." 27 Why did the demons howl at the origin of written script? Xushen 許慎 (ca. $100 \mathrm{CE}$ ), compiler of the Explaining Graphs and Analyzing Compounds (Shuowen jiezi 説文解字), noted the following about this passage, "By gazing at the patterns of the footprints of birds, Cangjie created writing in correspondence to them, then . . the demons feared that they also might be engraved in books and therefore they howled at night." ${ }^{28}$ In other words, to know the name or "true-form" (zhenxing 真形) of a spirit meant that one had control over that spirit. This theory of naming power has a long history in China, as it does elsewhere in the world. ${ }^{29}$

Written talismans, by virtue of their unique position somewhere between the "legible" and "illegible," between the "spirit world" and the "human world," served as mediums for communication with (or control of) the realm of demons and deities. Talismanic script could express or illustrate ineffable meanings and powers that defy transmission by traditional modalities of communication: oral or written. ${ }^{30}$ Talismans were sacred images that mirrored the forms of the primordial energies at the inception of the world and were therefore imbued with a spiritual power drawn from an ability to share in the essence of the thing it names or represents. ${ }^{31}$

\footnotetext{
25 See Vandermeersch, Wangdao ou la voie royale, 477 and 479, cited in Lagerwey, "The Oral and Written in Chinese and Western Religion," 301-2.

26 On the notion of "wen," see, e.g., Chaves, "The Legacy of Ts' ang Chieh"; and more recently Martin Kern, "Ritual, Text, and the Formation of the Canon: Historical Transitions of Wen in Early China," T'oung Pao 87 (2001): 43-91.

${ }^{27}$ Huainanzi 8 [Zhuzi jicheng, 116-17]. See also William Acker, Some T'ang and PreT'ang Texts on Chinese Painting (Westport, CT: Hyperion, 1954), 63 n. 1. On the power of written traces see Chaves, "The Legacy of Ts'ang Chieh."

28 Acker, Some T'ang and Pre-T'ang Texts, 63 n. 1; and Seidel, "Imperial Treasures and Taoist Sacraments," 322.

29 An interesting discussion of name magic can be found in Maurice Godelier, Perspectives in Marxist Anthropology (London: Cambridge University Press, 1977), 196-203. See also Walter Ong, Orality and Literacy: The Technologizing of the Word (New York: Routledge, 1982), 33; and Tambiah, "The Magical Power of Words."

${ }^{30}$ On the comparative context of using what appears to be illegible script as a medium for communication with the higher realm of spirits, see Gager, Curse Tablets and Binding Spells from the Ancient World, 9-10.

${ }^{31}$ In the Zhen'gao 真誥 [Declarations of the perfected], for example, there appears to be a hierarchy of spiritual potency that places script unintelligible to humans on the top; see Ledderose, "Some Taoist Elements in the Calligraphy of the Six Dynasties," 256. On the "primordial" or "celestial" provenance of Daoist talismans, see Jean Francois Billeter, The Chinese Art of Writing (New York: Rizzoli International, 1990), 256.
} 
This depiction of the specific nature of talismanic language within Chinese sources resonates well with other studies, especially Stanley Tambiah's seminal essay entitled "The Magical Power of Words," that have gone a long way toward revising earlier theories that interpreted "unintelligible" script or speech as mere gibberish. ${ }^{32}$ The esoteric language found in Chinese talismanic writing and in a variety of texts from the ancient Mediterranean world does not descend to the level of nonsense but is elevated to the level of being representative of the language used in spiritual conversations with higher orders. It is, in other words, the rarefied language of the gods and not a tainted or debased form of human language.

THE VISIBLE AND THE INVISIBLE: SEEING BUDDHIST TALISMANS

While there has been ample discussion about the role of esoteric talismans within Daoism and Chinese folk religion, there is a paucity of studies on their role within Buddhism. To be sure, this absence is not merely due to the modern scholarly prejudices discussed above. Some early Buddhist texts already contain clear critiques of the use of charms and amulets. The Brahmajāla Sutta, in the Dìgha Nikāya collection, says: "Whereas some ascetics and Brahmins, feeding on the food of the faithful, make their living by such base arts, such wrong means of livelihood as palmistry, divining by signs, portents, dreams, body-marks, mouse gnawings, fire-oblations, oblations from a ladle of husks, rice-powder, rice grains, ghee or oil, from the mouth or of blood, reading the finger-tips, house- and gardenlore, skill in charms, ghost-lore, earth-house lore, snake-lore, poison-lore, rat-lore, bird-lore, crow-lore, foretelling a person's life span, charms against arrows, knowledge of animals' cries, the ascetic Gotama refrains from such base arts and wrong means of livelihood." ${ }^{33}$ Now, if one were to turn to certain Chinese primary sources, it would also seem that the production and usage of talismans was adamantly rejected by Chinese Buddhists and was the sole prerogative of Daoists. The New Account of Tales of the World (Shishuo xinyu 世説新語) includes a fascinating (albeit polemical) account about a Buddhist monk whose healing techniques demonstrated the obstacles that might be encountered through the use of Daoist talismans.

Ch'ih Yin believed in the Taoist religion with zealous devotion. Once he was suffering from an ailment in his bowels, which various Taoist physicians were unable to cure. Hearing that the Buddhist monk Yu Fa-k'ai had a good reputation, he went to consult him. After he had come, Fa-k'ai took his pulse and

\footnotetext{
32 Tambiah, "The Magical Power of Words"; and see the discussion of that work in Gager, Curse Tablets and Binding Spells from the Ancient World, 9-10.

${ }^{33}$ This passage from the Brahmajala Sutta is translated in Maurice Walshe, Thus Have I Heard: The Long Discourses of the Buddha (London: Wisdom Publications, 1987), 71.
} 
said, "What your Excellency is suffering from is caused by none other than an excess of zeal [ching-chin], that's all." Whereupon he mixed a dose of medicine with some hot water and gave it to him. No sooner had Ch'ih taken his medicine than immediately he had an enormous bowel movement in which he evacuated several wads of paper, each as big as a fist. When he opened them up to look, they turned out to be the Taoist paper talismans $[f u]$ he had ingested earlier. ${ }^{34}$

Clearly the earlier Daoist talismans had not done the job, and this story represents the Buddhist rejection of the efficacy of talismans in general. Nonetheless, despite the negative assessment of the use of talismans in Chinese Buddhism suggested by this fifth-century source and reiterated by much modern scholarship, there is evidence that suggests that there was no consensus on the usage of talismans within early Chinese Buddhism. In the Discourse on the Profound Meaning of the Lotus Sütra (Fahua xuanyi 法華玄義), for example, the great Tiantai Buddhist master Zhiyi 智顗 (538-97) wrote-citing the apocryphal Sütra of Trapusa and Bhallika (Tiwei boli jing 提謂波利經)—“If you hope to attain immortality, then affix [to your body] the talisman $[f u]$ of longevity, ingest the medicine of immortality, and grasp the seal [yin 印] of eternal happiness." 35 Does Zhiyi's use of talismans and seals represent a lone voice in the Buddhist tradition or were talismans more pronounced in Chinese Buddhism than has heretofore been acknowledged?

The absence of studies and references to the Buddhist uses of talismans is connected to questions about the types of sources that have traditionally been used to delineate the parameters of Buddhist practice, a perduring tendency to erect rigid partitions between Buddhism and Daoism, and the refusal to recognize shared practices (particularly those that have been classified as being of a "magical," and therefore denigrated, character) between those two traditions. While it is true that talismans are found less frequently in the Buddhist canon (Taishō shinshū daizōkyō 大正新 修大藏經, hereafter Taishō) than in the Daoist canon (Zhengtong Daozang 正統道藏。 hereafter Daozang) where they appear regularly, one place where they do appear with some frequency is in Buddhist texts that

\footnotetext{
${ }^{34}$ Translation from Richard B. Mather, Shi-shuo Hsin-yü: A New Account of Tales of the World (Minneapolis: University of Minnesota Press, 1976), 361, with some changes.

${ }^{35}$ T. 33.804a5-7. The Tiwei boli jing 提謂波利經 does not survive intact, but quotations from that text are found in many later works, including the writings of Zhiyi 智顗 (538-97). For further studies on the Tiwei boli jing, see Makita Tairyo 牧田諦亮, Gikyo kenky $\bar{u}$ 疑經研 究 (Kyoto: Kyoto daigaku jinbun kagaku kenkyū jo, 1976), 148-211; Tsukamoto Zenryū 塚 本善隆, Tsukamoto Zenrȳu chosakushū 塚本善隆著作集 (Tokyo: Daitō shuppansha, 1974), 2:203, 204; and Whalen Lai, "The Earliest Folk Buddhist Religion in China: Ti-wei Po-li ching and Its Historical Significance," in Buddhist and Taoist Practice in Medieval Chinese Society, ed. David Chappell (Honolulu: University of Hawaii Press, 1987), 11-35.
} 
have been conventionally identified as esoteric or proto-Tantric. ${ }^{36}$ Other evidence points to the fact that their usage was pronounced in Chinese apocryphal works and in a variety of Dunhuang manuscripts and fragments. Recent research has shown the important role that Chinese apocryphal texts played in the development and adaptation of Buddhism in China, and therefore it is not surprising to find a significant indigenous Chinese practice (the writing of talismans) incorporated into primarily apocryphal Buddhist texts since "it is apocryphal texts, rather than exegeses of translated Indian scriptures, that often exhibit what is most distinctively Chinese about Chinese Buddhism."37

There are a number of recent studies regarding the Buddhist cult of the book and the way that Buddhist texts functioned like talismans, rather than as mere repositories of doctrinal teachings that were meant to be read. ${ }^{38}$ There has been less attention paid, however, to the talismans themselves that are found within Buddhist texts. Perhaps, one of the difficulties of locating talismans within Buddhist sources is that in most cases there is nothing in the title of a text that signals that it contains talismans. As will become clear below, many texts that are labeled as dhārañi sütras-which have traditionally been considered to be composed of oral formulationsalso contain written talismans and some dhäraṇi sūtras mention that their oral formulas should take a written form. ${ }^{39}$

One scholar who was at the forefront of a movement within Sinology to recognize practices and rituals common to Buddhists and Daoists was, of course, the late Michel Strickmann. In his foundational study on the use of "seals" (yin)—which use engraved wooden stamps in talismanic ways-in Chinese magico-religion, Strickmann proposed that the "use of

\footnotetext{
${ }^{36}$ See, e.g., the large number of entries in Lionel Giles, Descriptive Catalogue of the Chinese Manuscripts from Tunhuang in the British Museum (London: Trustees of the British Museum, 1957), that either mention talismans ( $f u$ ) in the title or are described as being magical charms (by which Giles usually refers to talismans). See also the charm and references to other recently discovered charms in the entry by Alan Atkinson for a "Tantric Buddhist Charm" (catalogue no. 34) in Latter Days of the Law: Images of Chinese Buddhism 850-1850, ed. Marsha Weidner (Honolulu: University of Hawaii Press, 1994), 296-98.

${ }^{37}$ On this important genre of sources, see Robert E. Buswell Jr., ed., Chinese Buddhist Apocrypha (Honolulu: University of Hawaii Press, 1990), 14. On the use of talismans in the Buddhist apocrypha, see Christine Mollier, "Les talismans du Buddha et de Laozi pour 'accroître le capital-vie,'” in Études de Dunhuang et Turfan, ed. Jean-Pierre Drège and Olivier Venture (Geneva: Librairie Droz, 2007), 155-88.

${ }^{38}$ See, e.g., Robert F. Campany, "Notes on the Devotional Uses and Symbolic Function of Sūtra Texts as Depicted in Early Chinese Buddhist Miracle Tales and Hagiographies," Journal of the International Association of Buddhist Studies 14, no. 1 (1991): 28-69; and Donald S. Lopez Jr., Elaborations on Emptiness: Uses of the Heart Sūtra (Princeton, N.J.: Princeton University Press, 1996).

${ }^{39}$ Paul F. Copp, "Voice, Dust, Shadow, Stone: The Makings of Spells in Medieval Chinese Buddhism" (Ph.D. diss., Princteon University, 2005); see esp. chap. 6, "Sūtra, Relic, Talisman: Transformations of Spell Writing, ca. 400-1100.”
} 
seals in Buddhism and Daoism richly illustrates our long-held contention that such pervasive phenomena cannot be parceled out into sectarian pigeon holes. It is fruitless to ask (as so often is done) 'is it Buddhist or Daoist?' Clearly, therapeutic sigillation has been both Buddhist and Daoist, and more besides." 40 This conscious breaching of the carefully delineated (albeit artificial) sectarian lines allows us to see that the use of seals was not only present in Daoist sources, but that they were also pervasive in Buddhist sources, and the same can be said of written talismans. We now have some foundational studies on talismans found in Buddhist sources by Gao Guofan 高國籓, Xiao Dengfu 蕭登福, Jean-Pierre Drège, and Christine Mollier that clearly demonstrate that Strickmann's work on seals merely touched the tip of an enormous iceberg floating in Daoist and Buddhist waters. ${ }^{41}$

There are many Buddhist texts found in standard collections, such as the Taishō canon, the Continued Buddhist Canon (Dai Nippon zokuzōkyō 大日本續藏經), and in Dunhuang manuscript collections, that incorporate talismans-or talismanic writing in an esoteric form of script. ${ }^{42}$ In order to give a sense of the extent to which Buddhist texts incorporated talismans and talismanic writing I will first recall some of the texts readily available

\footnotetext{
${ }^{40}$ Michel Strickmann, "The Seal of the Law: A Ritual Implement and the Origins of Printing," Asia Major 6, no. 2 (1993): 82. Strickmann's research now appears in a chapter titled "Ensigillation: A Buddho-Taoist Technique of Exorcism" in his book Chinese Magical Medicine (Stanford, CA: Stanford University Press, 2002). It will be clear to those who have read Strickmann's pioneering work how much this section of my essay owes to Strickmann's groundbreaking research. One of the main goals of Strickmann's series of articles was to rethink the connection that Paul Pelliot posited between the use of seals and the origin of printing in China. Yet, in the primary sources I was studying it was clear that while ensigillation and talismanic writing were two complementary entities, they needed to be dealt with on their own terms. Therefore, I have focused my attention here on what Strickmann merely hinted at in his study, namely, the uses of talismans and talismanic script. Now, see also the relevant study of Edward L. Davis, Society and the Supernatural in Song China (Honolulu: University of Hawaii Press, 2001).

${ }^{41}$ Gao Guofan 高國籓, Zhongguo minsu tanwei 中國民俗探微 (Jiangsu: Hehai daxue chubanshe, 1989), and 高國籓, Dunhuang minsu ziliao daolun 敦煌民俗資料導論 (Taibei: Xinwen feng, 1994); Xiao Dengfu 蕭登福, Daojiao shuyi yu mijiao dianji 道教術儀與密教 典籍 [Daoist techniques and esoteric Buddhist texts] (Taiwan: Xinwen feng, 1994); and Mollier, "Talismans," Mollier, "Les talismans du Buddha et de Laozi," and Mollier, Buddhism and Taoism Face to Face: Scripture, Ritual and Iconographic Exhange in Medieval China (Honolulu: University of Hawaii Press, 2008).

${ }^{42}$ Taishō shinshū daizōkyō 大正新修大藏經, ed. Takakusu Junjirō 高楠順次郎 et al., 100 vols. (Tōkyō: Taishō Issaikyō kankōkai, 1924-32); Dai Nippon zokuzōkyō 大日本續藏經, ed. Nakano Tatsue 仲野達慧 (Kyoto: Zōkyō shoin, 1902-5). Reprinted as Xuzang jing 續藏 經, 150 vols. (Taibei: Xinwenfeng, 1968-78). The reference here to Dunhuang manuscripts refers to the discovery during the early twentieth century of a large cache of documents and paintings at the Caves of the Thousand Buddhas (Qianfo dong 千佛洞) near the town of Dunhuang in modern Gansu Province located in the far western part of China. The discovery of these materials has led to a radical re-visioning of the nature of Chinese Buddhism and Daoism.
} 
in the Taisho canon. I will then turn to a more detailed treatment of some surviving Dunhuang manuscripts and focus on two that are representative of the vast material available among those manuscripts.

In spite of the claims by some scholars that these talismans are evidence of the existence of Tantric or proto-Tantric Buddhism in China, it is my contention that the tendency to classify these talismans as Tantric is primarily due to the ways that they have traditionally been classified and discussed in modern Euro-American and Japanese secondary literature, as well as the ways that some of texts with talismans have been categorized by the editors of the modern Taish $\bar{o}$ canon. ${ }^{43}$ One of the significant contributions of recent scholarship on talismans and spells is the mutual concern for the intersections between Buddhism and Daoism, yet in much of that work the invocation of Tantrism has served to separate off concerns for magic and spells within Buddhism into a hermetically sealed category in order to preserve the rest of Buddhism from these so-called debased or benighted practices. Yet, the use of charms, spells, and talismans are found within mainstream Buddhist texts and cannot be limited to any one lineage or tradition within Buddhism.

In the section that follows, therefore, there is only occasional reference to central Chinese Buddhist masters or well-known esoteric sūtras. Rather, the emphasis in these texts is on a world populated as much by gangs of demons, star deities, and magical spells as it is by buddhas and bodhisattvas. The following sources offer one vantage point from which to view how Buddhist texts creatively assimilated the distinctive Chinese practice of using an esoteric script to write talismans and how talismanic writing became a shared practice that is found within Buddhism and Daoism.

The applications of the Buddhist talismans discussed below are quite varied, but they generally include those that are to be ingested, those that are to be burned and the ashes used to empower water for washing the eyes or drinking, those to be hung up to garrison a home, applied to a bed,

\footnotetext{
${ }^{43}$ Most texts with talismans are situated in the "esoteric" (mikkyo $b u$ 密教部) section of the modern Taisho canon. This classification system is followed by Xiao Dengfu in his work, but we should note in addition that Michel Strickmann also classified these types of sources as "proto-Tantric." While Gao Guofan situates the talismans found in Dunhuang manuscripts in relationship to popular religious practices and Daoism, he also discusses their proliferation during the reign of Tang Xuanzong, which he states began to evince the teachings of Tantric or Esoteric Buddhist via the influence of masters such as Amoghavajra. The nature of Chinese Esoteric Buddhism and Chinese Tantrism has recently been rethought by Robert Sharf in his "Appendix" in Coming to Terms with Chinese Buddhism: A Reading of the Treasure Store Treatise (Honolulu: University of Hawaii Press, 2002); and by Richard D. McBride II in two related articles: "Is There Really 'Esoteric' Buddhism?" Journal of the International Association of Buddhist Studies 27, no. 2 (2004): 329-56, and "Dhāranī and Spells in Medieval Sinitic Buddhism," Journal of the International Association of Buddhist Studies 28, no. 1 (2005): 85-114.
} 


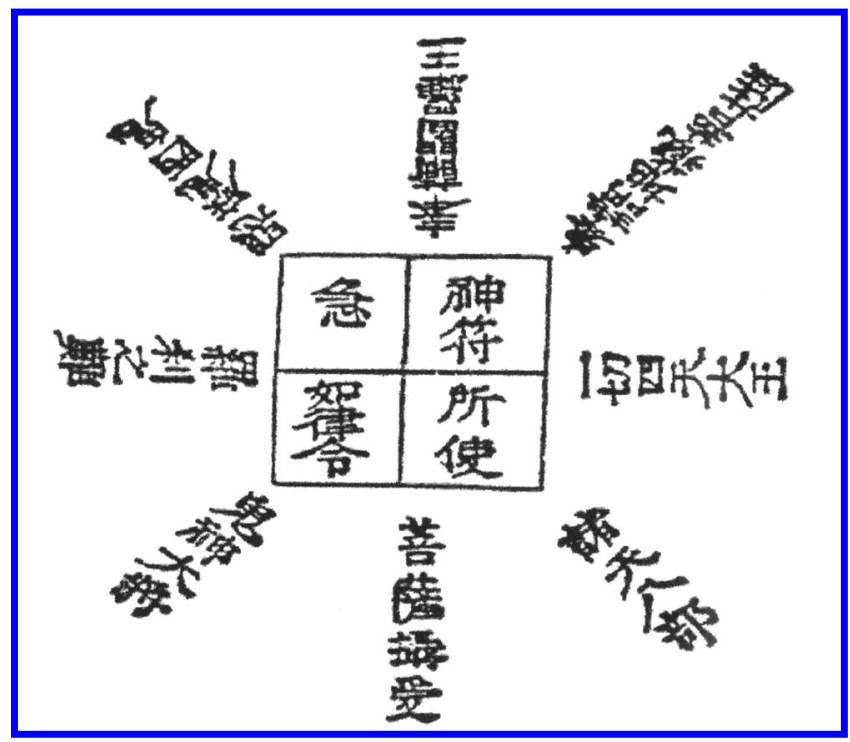

Fig. 2.-Talisman from the Dhärañi Sūtra of Ātavaka, General of Demons (T. 21.184a). Source: For all texts from the Taisho canon (figs. 2-8 and 10; citation beginning with T.), see Taishō shinshū daizōkyō 大正新修大藏經, ed. Takakusu Junjirō 高楠順次郎 et al., 100 vols. (Tokyo: Taishō Issaikyō kankōkai, 1924-32).

put on a tree, garrison a tomb, and those to be worn to become invisible. ${ }^{44}$ Interestingly, there are also talismans that are specifically designated as being for both Daoist and Buddhist monks to wear for good fortune, and a talisman found in later collections is to be affixed to the wall of a Daoist abbey or Buddhist monastery. ${ }^{45}$

One of the earliest Buddhist texts to include talismans is the Dhärani Sūtra of Ạtavaka, General of Demons (Azhapoju guishen dajiang shangfo tuolouni jing 阿吒婆句鬼神大將上佛陀羅尼經), dated to the first half of the sixth century (see fig. 2). ${ }^{46}$ It may on first glance appear odd to find written talismans in a dhārañi sūtra, since scholars have tended to separate

${ }^{44}$ Gao Guofan, Zhongguo minsu tanwei, 68-85; and Jean-Pierre Drège, "Du Texte à l'image," in Images de Dunhuang: Dessins et pientures sur papier des fonds Pelliot et Stein (Paris: École française d'Extrème-Orient, 1999), 105-68.

${ }^{45}$ Gao Guofan, Zhongguo minsu tanwei, 73; and see also the discussion in Sakade Yoshinobu 坂出祥伸, “Shōki mikkyō to dōkyō to no kōshō 初期密教と道教との女称," in Chūgoku Mikkyō 中国密教, ed. Tachikawa Musashi 立川武蔵 and Yoritomi Motohiro 頼富 本宏 (Tokyo: Shunjusha, 1999), 153-69.

${ }^{46}$ T. 21, no. 1238 . See Xiao Dengfu, Daojiao shuyi yu mijiao dianji, 279ff., on this text, and on the dating, see Strickmann, Chinese Magical Medicine, 143-51. 
these two into categories of writing and orality, but recently Paul F. Copp has shown that those categories were not mutually exclusive. ${ }^{47}$ The first image that we are presented with in this text is described as a talisman $(f u)$ to be used against disease demons. One of the conspicuous aspects of this talisman is the fact that it is written in a standard script that is all completely legible and may (if this text is true to its date) suggest that Buddhists initially wrote talismans in standard script before adopting the esoteric talismanic script that is common in contemporary Daoist texts and (as we will see shortly) Buddhist talismans found in later sources.

The Átavaka talisman has at its center a square box partitioned into four sections and radiating out from this square are all the names of the spirits who become present in the talisman when it is "activated" by reciting a spell twenty-one times. ${ }^{48}$ The center of the talisman contains a command derived from a phrase used to close Han dynasty official orders: "May those who are ordered by this spirit talisman be quick as the statutes and ordinances! (jiji ruliu ling 急急如律令)." ${ }^{49}$ Following the image of the talisman we read that those who "wear this talisman will be free of nightmares, if they wear it and enter battle they will be assured of victory, if they enter water they will not drown, and if they enter fire they will not be burned," all uncommon traits that are commonly ascribed to Daoist transcendents. ${ }^{50}$ Essentially this talisman functions as an all-purpose protective device that is empowered by the deities it commands.

Another set of talismans is found in a text dated roughly to the midseventh century, entitled Dhārañi Sūtra of Jāingulī, The Poison Woman, Spoken by the Buddha (Foshuo Changjuli dunu tuoluoni zhoujing 佛説常 㫿利毒女陀羅尼咒經) (see figs. 3 and 4). ${ }^{51}$ In line with the goddess Jāngulī's particular powers against malevolent dragons and serpents, her spell is known to be extremely effective against all forms of toxic envenomation. ${ }^{52}$ Thus, the talismans that are included in this text are also

\footnotetext{
${ }^{47}$ Copp, "Voice, Dust, Shadow, Stone: The Makings of Spells in Medieval Chinese Buddhism," 237-99.

${ }^{48}$ The combination of some type of physical movement while writing a talisman or carving a seal is a common feature found in these texts but is also a practice with ancient roots. See Harper, Early Chinese Medical Literature, 159ff. On the subject of movements and gestures in relation to healing, see Herbert Fischer, "The Use of Gesture in Preparing Medicaments and in Healing," History of Religions 5, no. 1 (1965): 18-53.

${ }^{49}$ T. 21.184a16. On the early provenance of this phrase in Han official documents, see A. F. Hulsewé, "Han Time Documents," T'oung Pao 45 (1957): 1-50; and Seidel, "Traces of Han Religion," 39ff.

${ }^{50}$ T. 21.184a25-28; and Strickmann, Chinese Magical Medicine, 145.

${ }^{51}$ T. 21, no. 1265. See the discussion of this text in Xiao Dengfu, Daojiao shuyi yu mijiao dianji, 302.

${ }^{52}$ For a brief mention of Jāngulī in India, see Ronald M. Davidson, Indian Esoteric Buddhism: A Social History of the Tantric Movement (New York: Columbia University Press, 2002), 231. On her powers against envenomation, see Strickmann, Chinese Magical Medicine, 151.
} 


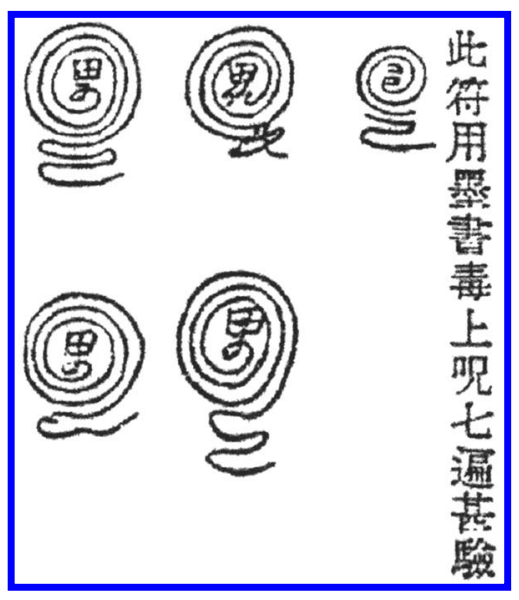

FIG. 3.-Talisman from the Dhäranī-Spell Sūtra of Jāngulī, The Poison Woman, Spoken by the Buddha (T. 21.295a).

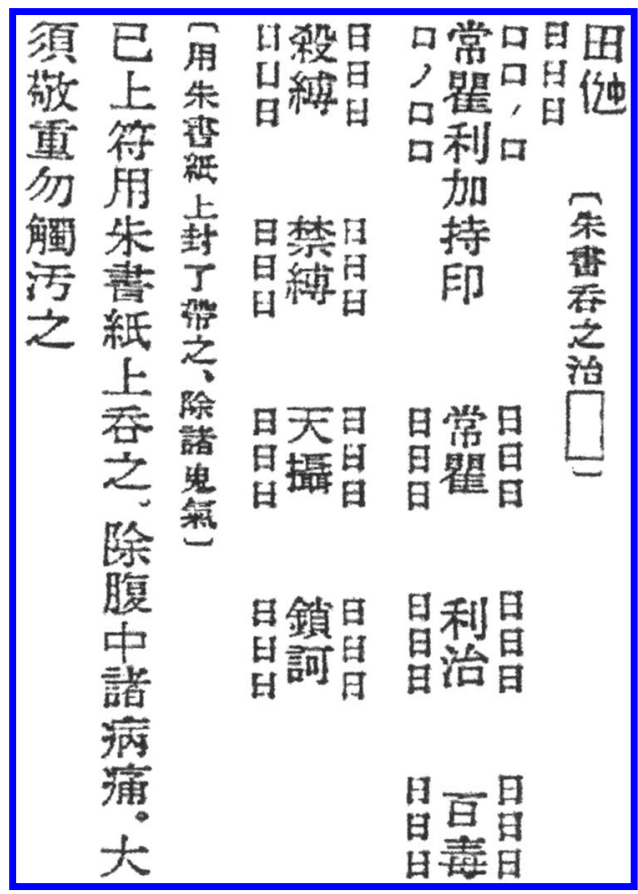

Fig. 4.-Talisman from the Dhärani-Spell Sūtra of Jāingulī, The Poison Woman, Spoken by the Buddha (T. 21.295a). 
specifically directed at dealing with envenomation. The first five talismans are represented by curling concentric circles that appear to have the graph for demon ( $g u i$ 鬼) written in talismanic script inside the serpentine coils.

The text informs us that these talismans are to be "drawn in black ink upon the point of envenomation." 53 A note to these talismans says that they can also be "written in vermilion ink on paper and swallowed to cure ... [text missing]." 54 Then follows another talisman that, like the Átavaka talisman, is written in standard script. The talisman says: "Ritual seal of Jāngulī; Jānguli cures the hundred envenomations! Kill and bind! Enchant and bind! Apprehend, goddess! Svāhā!" 55 The text notes that the talisman can either be written in vermilion on paper and carried on one's person to repel all demonic pneumas (guiqi 鬼氣), or it can be written in vermilion ink on paper and swallowed to get rid of stomach ailments. These talismans contain a mixture of standard and talismanic script, could be used internally as well as externally, and function like an official written order or command.

The canonical Buddhist text that includes the richest account of talismans to be worn ( $p e i$ 佩) or ingested ( $f u$ 服) is Nāgārjuna's Treatise on the Five Sciences (Lungshu wuming lun 龍樹五明論), compiled perhaps as early as the sixth century (see fig. 5). ${ }^{56}$ Although the actual representations of the talismans do not appear until the end of this fascinating text, it is worth pausing at the beginning, since the first chapter contains some of the most detailed written information on talismans found in any source. The first mention of talismans in this text occurs in a list of three talismans that can “attract wealth” (zhao caibao 招財寶), “cure the illnesses of sentient beings" (zhi zhongsheng bing 治眾生病), and “command the proper timing of wind and rain." 57 Then the text contains a lengthy section that provides precise details about eighteen different talismans (none of which is illustrated). All of these talismans are to be written in vermilion on silk and either worn or carried. Strickmann has summarized their powers as follows: "In addition to talismans for treating diverse maladies and prophylactic use against disease demons, government officials, and other robbers, this list includes talismans to aid in childbirth, others to restore harmony, as well as one guaranteed to instantly obtain high-ranking suitors for an

${ }^{53}$ T. 21.295a; and Strickmann, Chinese Magical Medicine, 153.

54 T. $21.295 \mathrm{~b} 1$.

55 T. 21.295b, translation in Strickmann, Chinese Magical Medicine, 153. For an interesting cross-cultural perspective on "binding spells," see Faraone, "The Agonistic Context of Early Greek Binding Spells"; and Alfred Gell, Art and Agency: An Anthropological Theory (Oxford: Clarendon, 1998), 114.

${ }^{56}$ T. 21 , no. 1420 . See Xiao Dengfu, Daojiao shuyi yu mijiao dianji, $399 \mathrm{ff}$. On the dating of this manuscript, see Strickmann, Chinese Magical Medicine, 170-78.

${ }^{57}$ T. $21.956 \mathrm{c} 28-957 \mathrm{a} 1$. 


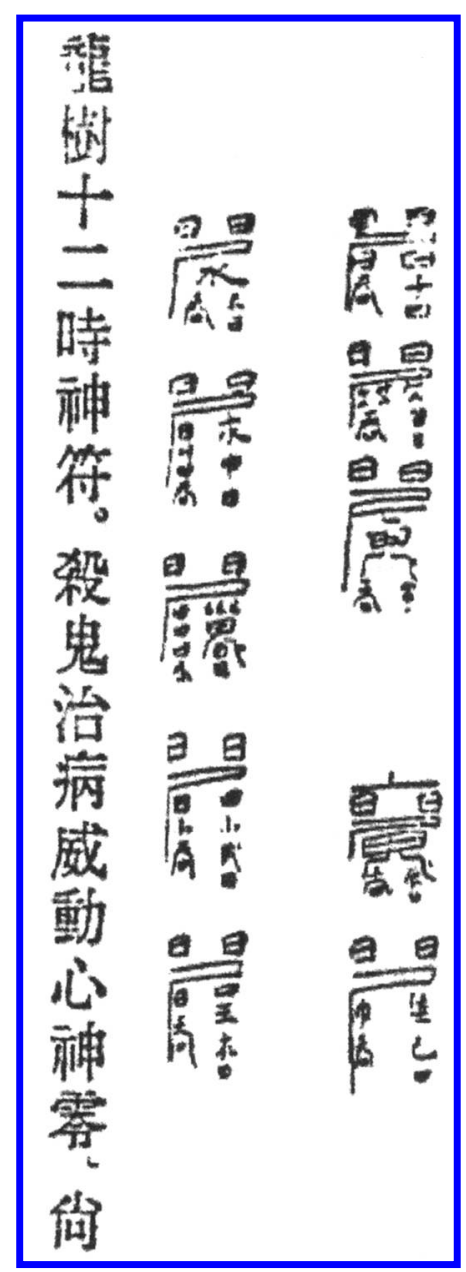

FIG. 5.-Talisman from Nāgārjuna's Treatise on the Five Sciences (T. 21.958c)

unwed daughter who is growing perilously old." ${ }^{58}$ In other words, these talismans were used to attract things that were desired, like wealth and so forth, and at the same time helped to repel disease demons and robbers.

Shortly after enumerating this list of talismans Nāgärjuna's Treatise on the Five Sciences goes on to list twelve more talismans (although only ten are pictured) that claim to "kill demons and cure diseases" (shagui

\footnotetext{
58 Strickmann, Chinese Magical Medicine, 171.
} 
zhibing 棂鬼治病). Significantly, these talismans are all to be ingested at particular times calibrated by a fixed Chinese astrological schedule. ${ }^{59}$

In this text, as in others, astrological knowledge is all important, and given the importance of astrology in the first part of the text it is no surprise to find that in the talismans and seals depicted at the end of the text we find a more liberal inclusion of astral, or pseudo-astral, depictions. ${ }^{60} \mathrm{We}$ are informed that "if a woman is undergoing difficult labor pains, administer a paper talisman imprinted with a seal for her to swallow, and the infant in her womb will speedily come forth holding the talisman in its hand."61 We are clearly a long way from the Shishuo xinyu tale that ridiculed the sick person for ingesting Daoist talismans written on paper! The first of the last three talismans included in this text focuses on the attainment of powers to deal with evil people, and it specifies that those who obtain this talisman are not to drink alcohol, eat meat or the five pungent foods (wuxin 五辛: onions, garlic, shallots, leeks, and chives, which are considered to induce lustful thoughts), and they are instructed not to transmit it carelessly to others. ${ }^{62}$ This talisman lacks the systematic appearance of other contemporary Daoist and Buddhist talismans and appears to be merely a bunch of wavy lines. The depictions of the last two talismans, which are both concerned with curing diseases, however, look more like the intricately formed talismans that appear in contemporary Daoist sources and what we find in later Buddhist sources and therefore may reflect the fact that there was a gradual movement from standard script toward esoteric script.

In the Secret Magical Techniques of the Ten-Thousand Loves of Mañjuśrì and Yamāntaka (Manshushili yanmandejia wanai mishu ruyi fa 曼 殊室利焰曼德迦萬愛祕術如意法) (see fig. 6), a text attributed to Yixing 一行 (683-727), the Chan monk who later became Subhākarasiṃha's disciple, there is also a set of two talismans that are labeled "earth talisman" and "heaven talisman."63

These two talismans, which include the head and the head and partial body of a human figure, are strange but do resemble a variety of Daoist

59 T. $21958 \mathrm{c}$.

60 T. $21.967 \mathrm{a} 1-3$. The astral images are particularly evident in the seals that are reproduced on 963-64.

61 See this story in Strickmann, "Seal of the Law," 62.

62 T. $21.967 \mathrm{~b} 3$.

63 T. 21, no. 1219. See Xiao Dengfu, Daojiao shuyi yu mijiao dianji, 251ff. On Yixing, see his biography in Song gaoseng zhuan T. 50.732c7-733c24; and the study by Osabe Kazuo 長 部和雄, Ichigyō zenji no kenkȳ 一行禅師の研究 (Kobe: Kōbe Shōka Daigaku Gakujitsu Kenkyūkai, 1963), which also discusses these talismans. Yamāntaka is a ferocious manifestation of Mañjuśri. See Alice Getty, The Gods of Northern Buddhism: Their History and Iconography (New York: Dover, 1988; first published 1914), 164. 


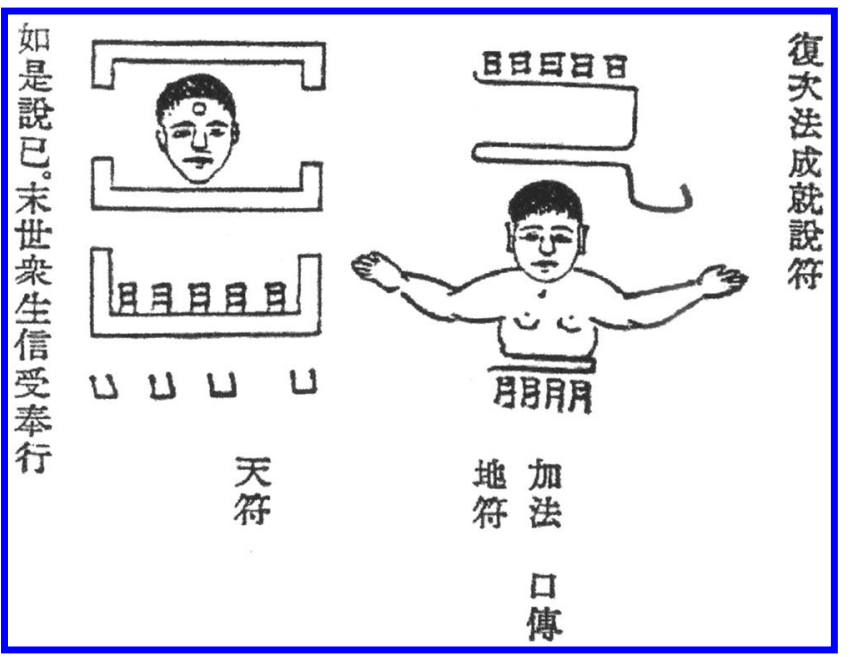

FIG. 6.-Talismans from Secret Magical Techniques of the Ten-Thousand Loves of Mañjuśrì and Yamāntaka (T. 21.97c).

talismans that are also capped with the head of a human being. ${ }^{64}$ Since there is no detailed explanation of these talismans, there is little we can say about them here, except to note that the practitioner is told to recite, rather than to write, ingest, or wear them. ${ }^{65}$ While we find here an oral element to talismans, there are also a number of texts labeled as dhārani sütras where we find instructions that stipulate that the dhäranī was to be written out and worn or ingested, rather than merely enunciated. ${ }^{66}$

Of the entire collection of written talismans found in Buddhist texts collected in the Taisho canon, the set that appears to be the most systematically drawn and the closest (in form) to pre-Daoist and Daoist talismans is the star talismans found in the Sütra Spoken by the Buddha on Prolonging Life by Worship of the Seven Stars of the Northern Dipper (Foshuo beidou

64 See, e.g., the Lingbao talisman depicted in Despeux, "Talismans and Diagrams," 516.

65 T. $21.97 \mathrm{c} 15$. The occurrence of the character $f u$ written with a double mouth radical rather than with the bamboo radical may suggest an early precedent for some talismans being representations of incantations.

${ }^{66}$ It is interesting to note that at least two other esoteric texts that contain talismans are also called dhäranì sūtras. See T. no. 1238 and T. no. 1265. For further relevant comments on dhāraṇ̄, see Ryūichi Abé, The Weaving of Mantra: Kūkai and the Construction of Esoteric Buddhist Discourse (New York: Columbia University Press, 1999), 159ff. and 166ff., where he distinguishes Mahāyāna dhāraṇī that are appendages to sūtras, and esoteric dhāraṇi that are used for healing and long life in Nara period Japan. In thinking about the issue of the oral nature of dhāranī, it is useful to consult David Frankfurter's work on the oral nature of talismans and amulets. See Frankfurter, "The Magic of Writing and the Writing of Magic." 
qixing yanming jing 佛説北斗七星延命經) (see fig. 7). ${ }^{67}$ These talismans draw extra potency from their correlation with specific stars due to the macrocosmic and microcosmic relationships between the celestial sphere and the human realm (including the inside of the body). In this text, the talismans are found under the name for each star in the Northern Dipper (beidou 北斗)—an asterism of great importance within the imperial cult, Daoism, Buddhism, and Chinese popular religion-and in the lower register of the text we are told that a person who is born under a certain chronogram is to wear that talisman if they encounter danger. ${ }^{68}$

Ostensibly the talismans that are found in this text also help the practitioners negotiate the list of ailments and dangers, and realize the worldly benefits, that are mentioned later in the text. That list includes protection from malevolent demons, official promotion, wealth and prosperity, curing of disease, and ease in childbirth. The list ends by reassuring the possessor of the talismans that the seven stars of the Dipper "control human destiny" (shenming 身命), that is to say, one's life span.

Another short text in the Taish $\bar{o}$ canon that combines text and talismans is the Rules for the Diviner's Board of the Holy Deity of Mirth (Sheng huanxitian shifa 聖歡喜天戎法). Robert Duquenne has shown that this curious text is an amalgamation of Chinese and Indian astral images. Two talismans are labeled "obscure character talisman" (mingwen fu 冥文符) for "prosperity" (sheng 盛) and a "talisman for mysterious captivation" (mishe fu 祕攝符) ${ }^{69}$ Unfortunately, the text does not describe the use of these talismans. Two notes below the images of the talismans merely say, "on the back, [the name of] so and so," and "tightly opposed to the surface, draw and cut." 70 This text contains a wide variety of Indian and Chinese elements, including Hindu deities, Sanskrit "seed syllables" (bijja), mudrās, talismans, and the familiar injunction "quickly, quickly in accordance with

${ }^{67}$ T. no. 1307. This text is the subject of a study and translation by Charles Orzech and James Sanford, "Worship of the Ladies of the Dipper," in Tantrism in Practice, ed. David Gordon White (Princeton, NJ: Princeton University Press, 2000), 383-95. See also Xiao Dengfu, Daojiao shuyi yu mijiao dianji, $347 \mathrm{ff}$.

${ }^{68}$ On the Northern Dipper in general, see, e.g., Edward H. Schafer, Pacing the Void: $T$ 'ang Approaches to the Stars (Berkeley: University of California Press, 1977), 157-62. On the role of the Dipper in Daoist ritual, see Poul Andersen, "The Practice of Bugang," Cahiers d'Extrême-Asie 5 (1990): 15-53. On the role of the Northern Dipper within Buddhism, see Yano Michio 矢野道雄, Mikkyō senseijutsu 密教占星術 (Tokyo: Tokyo Bijitsu, 1986), Morita Ryūsen 森田龍僊, Mikkyō senseihō 密教占星法 (Koyasan: Koyasan daigaku, 1941; repr., Rinsen shoten, 1975); and Charles Orzech and James Sanford's introduction to their translation of T. 130, Scripture Expounded by the Buddha on Prolonging Life through Worship of the Seven Stars of the Northern Dipper [Foshuo beidou qixing yanming jing].

${ }^{69}$ T. no. 1275. See the study and translation of this text by Robert Duquenne, "Ganapati Rituals in Chinese,' Bulletin l'Ecole Francaise d'Extrême-Orient, vol. 77 (1988), esp. 326ff.; and Xiao Dengfu, Daojiao shuyi yu mijiao dianji, $311 \mathrm{ff}$.

${ }^{70}$ Duquenne, "Ganapati Rituals in Chinese," 349. 


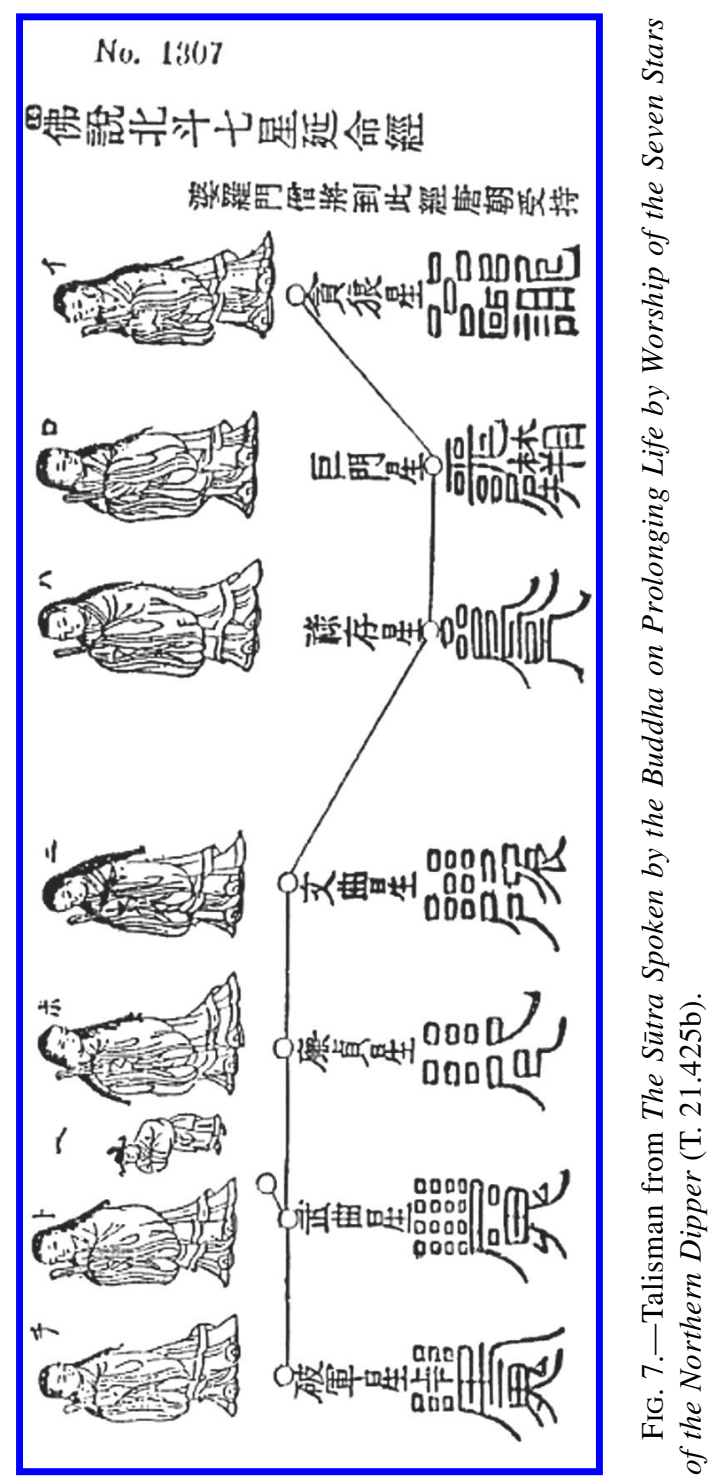




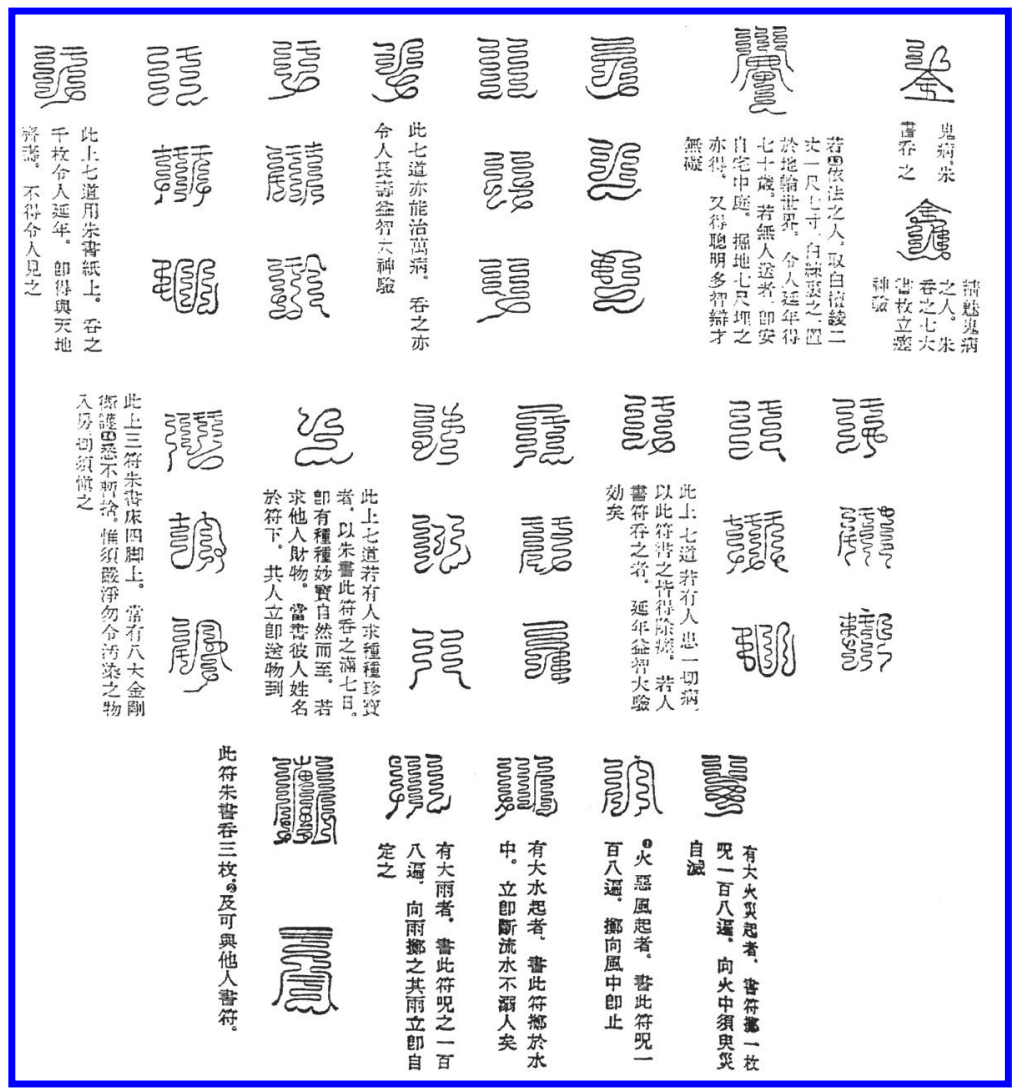

FIG. 8.-Talismans from the Scripture on the Rites of the Vajra-Being of Impure Traces [Ucchusma] for Exorcising the Hundred [Demonic] Transformations (T. 21.160-61).

the statutes and ordinances." 71 All of these techniques are combined for a variety of purposes: protecting oneself from diseases and spells cast by others, empowering oneself to cast spells on others (make them ill), and attaining specific material goods (other people's treasures, high rank, etc.).

Finally, the richest text for visual representations of talismans in the Taishō canon is the Scripture on the Rites of the Vajra-Being of Impure Traces [Ucchușma] for Exorcising the Hundred [Demonic] Transformations (Huiji jingang jin baibianhua fa jing 穢跡金剛禁百變化法經) (see fig. 8). ${ }^{72}$ After presenting four seals and their immense powers-which

71 T. $21.324 \mathrm{~b} 12$.

72 T. no. 1229. See Strickmann, "Seal of the Law," 43 and Davis, Society and the Supernatural in Song China, 126-52. 
include attracting the love of others, the ability to fly, and the power to alleviate pain and suffering - the text depicts a total of forty-two talismans that are to be written on paper, written on the body, or written on paper and swallowed. All of these talismans are included in a section that is titled "Miraculous Rites for Prolonging Life."

The problems that these talismans claim to be effective against include both heart ailments and demonic illness. Other talismans in this list emphasize the ability to prolong one's life and increase one's knowledge (yannian yizhi 延年益智), and one talisman claims to ensure the attainment of treasures (bao 寶). ${ }^{73}$ If one covets someone else's valuables, the text boasts, all they need to do is to write the other person's name underneath the talisman and that person will immediately send the desired things to them. ${ }^{74}$ After depicting three talismans that are to be drawn on the four legs of one's bed in order to ensure the protection of the Eight Great Vajra Protectors (bada jingang weihu 八大金剛王), ${ }^{75}$ the next four talismans are all concerned with protection from natural disasters, including the dangers of fire, wind, excessive rain, and floods. ${ }^{76}$ Given what we have learned from other collections of talismans, it is not surprising to find that some of the talismans in this set also end with the "quickly, quickly in accordance with the statutes and ordinances" formula for ordering demons and deities, and that they also include injunctions ordering the possessor not to show them to other people. ${ }^{77}$ Edward Davis has noted that there was "no better example of Daoist influence on Tantric Buddhism" than in the texts of the early followers of Ucchușma's cult. ${ }^{78}$ While this may be true, we will see below that based on other evidence from Buddhist manuscripts from Dunhuang, establishing a clear direction of influence-from Daoism to Buddhism-is not as straightforward as one might expect.

\section{BUDDHIST TALISMANS IN DUNHUANG MANUSCRIPTS}

One of the problems with just referring to Buddhist texts in the Taisho canon that contain talismans is that the texts in that collection were drawn primarily from Japanese libraries and temple collections. ${ }^{79}$ The Taisho canon also provides a limited vantage point onto Buddhist talismans due

73 T. $21.160 \mathrm{c}$.

74 Ibid.

75 On these protectors, see Mochizuki Shinkō 望月信亨, ed., Bukkyō daijiten 仏教大辞典, rev. and enlarged ed., 10 vols. (Tokyo: Sekai Seiten Kankō Kyōkai, 1958-63), 4:3391. On the relationship of this talisman to aiding childbirth, see Gao Guofan, Zhongguo minsu tanwei, 80.

76 T. $21.1671 \mathrm{a}$.

77 T. $21160 \mathrm{a}$ and $160 \mathrm{~b} 29$.

78 Davis, Society and the Supernatural in Song China, 134.

${ }^{79}$ On the history of the compilation of the Taisho canon, see Silvio Vita, "Printings of the Buddhist 'Canon' in Modern Japan," in Buddhist Asia 1: Papers from the First Conference of Buddhist Studies Held in Naples in May 2001, ed. Giovanni Verardi and Silvio Vita (Kyoto: Italian School of East Asian Studies, 2003), 217-45. 
to the fact that the Dunhuang texts that were included by the editors came from the Stein collection in London, while other collections-such as the Pelliot collection in Paris-are not well represented. ${ }^{80}$ When we throw a wider net than did the Taisho editors, we find that there are at least fifty Dunhuang manuscripts that include Buddhist talismans or describe the production of talismans, but no longer include the images.

Included in the vast trove of paintings and books discovered in Dunhuang at the beginning of the twentieth century was a striking painted talisman on paper ( 42.7 centimeters [ 18 inches] high and 30 centimeters [11 inches] wide).$^{81}$ This talisman, found in the "library" of cave 17 at Dunhuang and now housed in the British Museum (Stein Painting \#170), is a particularly fascinating example of the mixing of text, talisman, and iconography (see fig. 9). The talisman comprises two registers (above and below) and a surrounding decorative motif that is akin to the outer "doors" found on Indian yantras. ${ }^{82}$

The lower register of the talisman can be divided into two sections. The right side is filled with a haphazard looking mixture of talismanic script, esoteric seal script, and a few recognizable elements of Chinese graphs. The talismanic writing closely resembles the type of script that is encountered in Daoist texts and the esoteric texts discussed above, but when compared to other intricate talismans preserved in contemporary Daoist Dunhuang manuscripts this fragment appears to be exceedingly simple and to be the product of an untrained hand. ${ }^{83}$ Indeed, this talisman looks like what might be produced by someone who was trying to copy or mimic the style of other talismans without understanding, or having mastered, the logic that goes into their construction. ${ }^{84}$ We might imagine a scene not

${ }^{80}$ See Mollier, "Talismans."

${ }^{81}$ Reported in Aurel Stein, Serindia (Delhi: Motilal Banarsidass, 1921), 2:1080. This copy is reproduced from Roderick Whitfield and Anne Farrer, Caves of the Thousand Buddhas: Chinese Art from the Silk Route (London: British Museum Publications, 1990), 83. See also the record in Arthur Waley, A Catalogue of Paintings Recovered from Tun-Huang by Sir Aurel Stein, K. C. I. E., preserved in the Sub-department of Oriental prints and drawings in the British Museum, and in the Museum of Central Asian antiquities, Delhi (London: Kegan Paul, 1931), 164. This painting was also discussed briefly in Christine Mollier, "Talismans," 409 and 424.

${ }^{82}$ Madhu Khanna, Yantra: The Tantric Symbol of Cosmic Unity (London: Thames \& Hudson, 1979).

${ }^{83}$ Fine examples of some facsimiles of extant Daoist talismans can be found in Ōfuchi Ninji 大淵忍爾, Tonkō Dōkyō: Zuroku hen 燉煌道教: 圖録篇 (Tokyo: Fukutake Shoten, 1979). Gao Guofan (Zhongguo minsu tanwei, 77) also writes about how Buddhists initially did not understand the usage of Daoist talismans.

${ }^{84}$ Despite the fact that these talismans were meant to reflect the illegible writing of the spirit world, research has shown that there came to be a logic used to write Daoist talismans. See, for example, the admirable efforts of interpretation undertaken by Wang Yucheng 王育成 in his “Tang Song Daojiao mizhuanwen shili 唐宋道教秘管文釋例.” On the interpretation of a talisman on an ordinance jar, see Li Ling, "An Archaeological Study of Taiyi (Grand One) Worship," Early Medieval China 2 (1995-96): 17; and Mu-chou Poo, In Search of Personal 


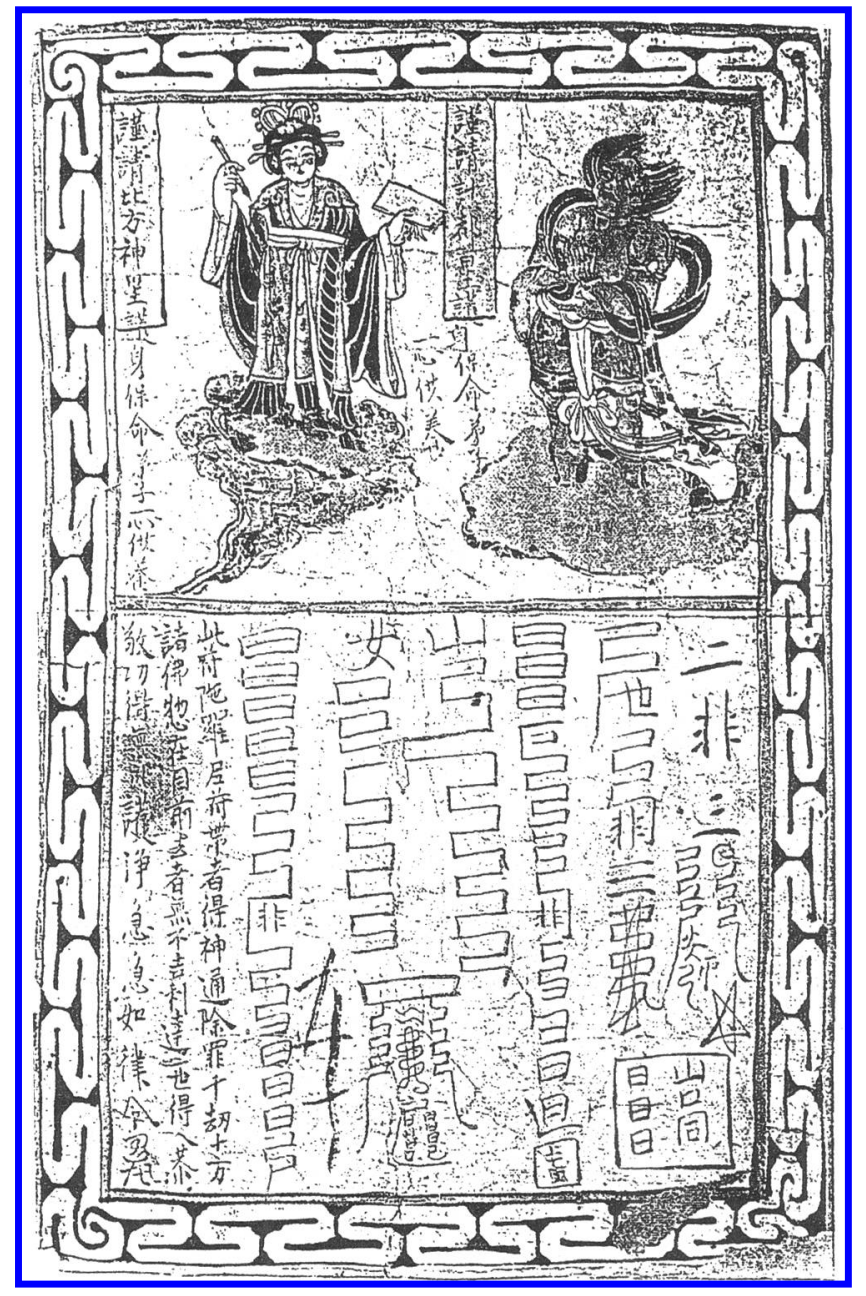

FIG. 9.-Stein Painting \#170, British Museum. After Roderick Whitfield and Anne Farrer, Caves of the Thousand Buddhas: Chinese Art from the Silk Route (London: British Museum Publications, 1990), 83. (C) The Trustees at the British Museum. 
completely unlike that found in an essay entitled "A Writing Lesson," in Lévi-Strauss's Tristes tropiques, where the Nambikwara chief mimicked Lévi-Strauss's writing by simply drawing wavy lines on the paper. ${ }^{85}$ Yet, rather than chuckle at that scene, we might speculate that, like the Nambikwara chief who sensed the purpose and power of writing and used it to maintain (or even increase) his power in the tribe, whoever was responsible for the production of this talisman sensed that this newly encountered style of talismanic writing also held power that could be tapped. This talismanic script was likely taken to be a dhäranī, and the mystic power that is usually rendered in Siddham-or transliterated-is here presented in a sinified form of an equally esoteric nature. ${ }^{86}$

The Chinese script on the left side of the lower register is entirely legible and announces the power of this talisman: "This talisman is a dhärani talisman [cifu tuolouni fu 此符陀羅尼符]. Those who wear it will obtain supernormal powers [shentong 神通, abhijñ $\bar{a}$ ] and will have their sins removed for a thousand kalpas. All of the Buddhas of the ten directions will appear before their eyes, and there will be nothing that is not auspicious or profitable. Throughout their entire life they will obtain the respect and admiration of others, and their merit will be without compare. [Actualize the] protection and purification, quickly, quickly in accordance with the statutes and ordinances!"87 In the upper register there are two deities, one female standing high on a red cloud holding a writing brush and a book, and the other a male demon-like figure standing on a green cloud with his hands in añjali-mudra (kong $\bar{o}-g a s s h \bar{o}$ 金剛合掌). It is significant to note, however, that in typical talismanic style all of the script on this talisman is written in vermilion ink (zhushu 朱書). The passage next to the female reads, " $[I]$ respectfully request that the spirit of the star of the northern quarter [i.e., the Pole Star] protect my body [from evil] and preserve [my] life. Your disciple presents [this] with [his/her] whole heart." The passage next to the male figure says, "[I] respectfully request that the planet Ketu

\footnotetext{
Welfare: A View of Ancient Chinese Religion (Albany: SUNY Press, 1998), 181. For an early article that attempted to point out how talismans might be broken down into discrete elements, see Ch'en Hsiang-Ch'un, "Examples of Charm against Epidemics with Short Explanations: With 15 Cuts of Charms," Folklore Studies 1 (1942): 37-54; and see the example from a modern talisman in Emily Martin Ahern, Chinese Ritual and Politics (Cambridge: Cambridge University Press, 1981), 25.

85 Claude Lévi-Strauss, Tristes tropiques (New York: Washington Square Press, 1973), 331-43; originally published in French in 1955.

${ }^{86}$ On the occurrence of dhärani being used like "spells," see Copp, "Voice, Dust, Shadow, Stone: The Makings of Spells in Medieval Chinese Buddhism"; and John Kieschnick, The Eminent Monk: Buddhist Ideals in Medieval Chinese Hagiography (Honolulu: University of Hawaii Press, 1997), 88.

${ }^{87}$ See also the translation by Waley in A Catalogue of Paintings Recovered from TunHuang, 165.
} 
protect my body [from evil] and preserve [my] life. Your disciple presents [this] with [his/her] whole heart." 88 While we would expect the other figure to be Rāhu, there is no evidence (as far as I can discern) to indicate that identification. $^{89}$

This talisman emphasizes the dual attainment of supramundane goals (visions of Buddhas and removal of sins) along with more mundane attainments (magical powers and admiration of others). Given the size and content of the text, one can well imagine that it is a surviving talisman of precisely the type that might have actually circulated..$^{90}$ In short, this Buddhist talisman is a fascinating example of an extracanonical source in which we see the incorporation of talismanic script that empowers it for use in purification and protection.

The final Buddhist text under consideration here presents a number of interpretive questions that complicate any attempt to assign a clear line of influence between Buddhism and Daoism. The Sütra of the Seven Thousand Buddhas Spirit Talismans Spoken by the Buddha (Foshuo qiqian fo shenfu jing 佛説七千佛神符經, hereafter Seven Thousand Buddhas Spirit Talismans) (see figs. 10 and 11), is a fragmentary text included in the Taisho Buddhist canon that is exclusively focused on the explication of a series of written talismans $(f u)$ but is also found in varying states of preservation among the Dunhuang manuscripts. ${ }^{91}$

88 This passage has also been translated in Waley, A Catalogue of Paintings Recovered from Tun-Huang, 165. On Rāhu and Ketu, see Michel Strickmann, Mantras et mandarins: Le bouddhisme tantrique en Chine (Paris: Gallimard, 1996), 488 n. 23. Ketu, originally a demon that devours the moon causing lunar eclipses, is here one of the powerful demons that, once converted, becomes an invincible Buddhist protector.

${ }^{89}$ Both Arthur Waley and Roderick Whitfield note the resemblance between this woman and representations of the planet Mercury. See Waley, A Catalogue of Paintings Recovered from Tun-Huang, 164; and Roderick Whitfield, The Arts of Central Asia: The Stein Collection in the British Museum; 2 Paintings from Dunhuang (Tokyo: Kodansha International, 1983), pl. 61.

${ }^{90}$ Christine Mollier has also suggested that this a "véritable" talisman, a talisman consecrated and ritually employed, as opposed to others that are models used for making copies. See Mollier, "Talismans," 409.

91 T. no. 2904. This text and its variants are found in a number of Dunhuang manuscripts including Stein 2708 (British Library), Pelliot 2723, Pelliot 3022r, and Pelliot 4667v (Bibliothèque nationale de France). Other variants include Pelliot 2558r (which in fact has a Daoist scripture on the reverse side) and Stein 4524. The Taishō version of the text serves as a good example of the limitations of merely using the Taisho canon in conducting research on these Buddhist manuscripts. The collection of Dunhuang sources included in that canon was drawn mainly from the Stein collection in London. In the case of this text the Stein manuscript was severely damaged, and the beginning of the text was missing, as is evident in the Taisho printing. Yet, in the Pelliot versions the first part of the text is intact. Therefore by collating all the extant versions of this text we can reconstruct a complete version of the manuscript. Christine Mollier notes that a fragment of this text was also found at Turfan (Ch. 2190r). See Mollier, "Talismans," 410. Masuo Shinichirō also lists P. 2153, which is presently in the Tōyō bunko 東洋文庫, as a related text. See Masuo Shinichirō 増尾伸一郎, “Nihon kodai no jufu 


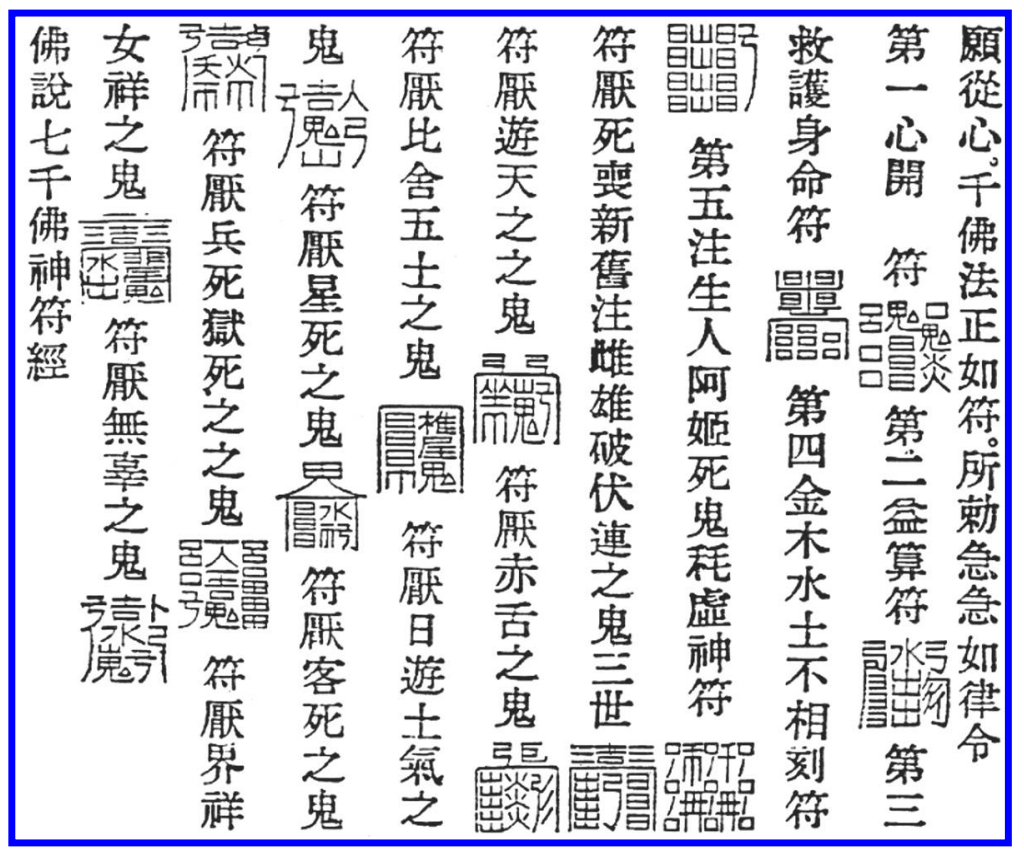

FIG. 10.—Seven Thousand Buddhas Spirit Talismans, Taishō version T. no. 2904

The focus of the first part of the Seven Thousand Buddhas Spirit Talismans is on the role of these talismans in the prolongation of life (yannian yisuan 延年益算). ${ }^{92}$ The primary concern related to extending one's years seems to involve securing the protection of the one who possesses the talismans from illness and disease demons. After advertising that the "thousand Buddha talismans" (qianfo fu 千佛符) are capable of beating and disciplining (daduan 打鍛) a variety of demons so that they all vanish of their own accord (jinzi xiaomie 盡自消滅), the text goes on to appeal to the controlling powers of the stars in the Northern Dipper (beidou 北斗). This text specifies that the stars of the Dipper signify the following: Army Destroyer (pojun xing 破軍星) controls “wasting”

bokukan, bokusho doki to gigi kyōten 日本古代の呪符木簡, 墨書土器と疑偽経典” $T \bar{o} y \bar{o}$ no shisō to shükyō 東洋の思想と宗教, no. 13 (1996): 78-104. The most detailed study of this text is now Mollier, "Les talismans du Buddha et de Laozi," which is available in English as "Augmenting the Life Account" that is the third chapter of her recent Buddhism and Taoism Face to Face, 100-133. Since the research for this article was completed some years ago and Mollier's work was only published recently, I was unable to take it fully into account here.

${ }^{92}$ On the compound yisuan (益算), see Hanyu da cidian 漢語大詞典, vol. 7, 1423. 


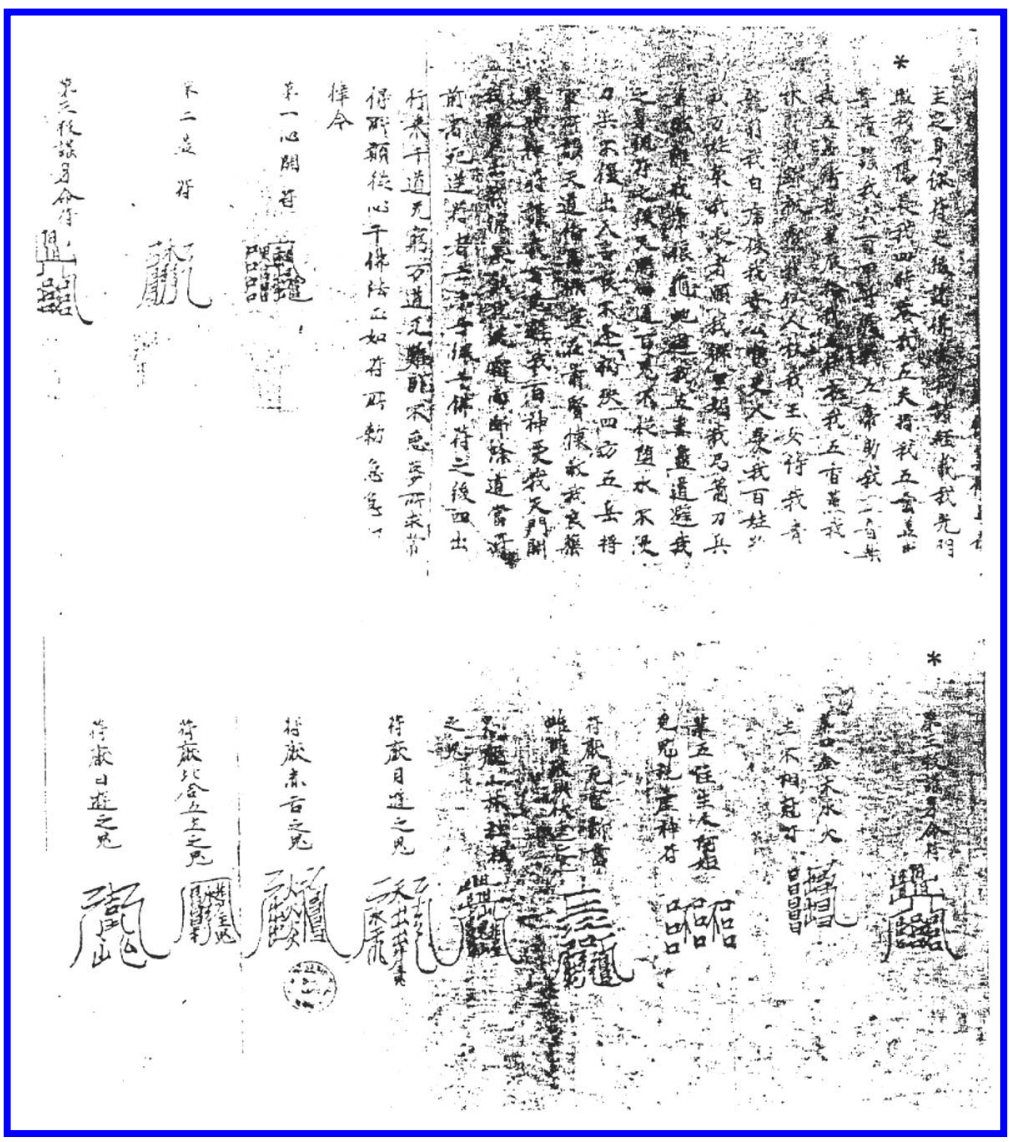

FIG. 11.-P. 2723, Seven Thousand Buddhas Spirit Talismans Dunhuang version. After Dunhuang Baozang 敦煌寶藏 [Treasures from Dunhuang] (Taibei: Xinwenfeng, 1981-86), 126:68. Courtesy of the Bibliothèque nationale de France.

(haoxu 秏虛); ${ }^{93}$ the star Militancy Song (wuqu xing 武曲星) controls official affairs (guanshi 官事); the star Honest and Pure (lianzhen xing 廉 貞星) controls disputes (koushe 口舌); ${ }^{44}$ the star Cultured Song (wenqu xing 文曲星) controls nightmares; the star Maintaining Happiness/Preserv-

93 On this ailment, see Morohashi Tetsuji 諸橋轍次, ed., Dai kanwa jiten 大漢和辭典, 13 vols. (Tokyo: Taishūkan Shoten, 1955-60), 9:175.

${ }^{94}$ On koushe, see Hanyu da cidian 漢語大詞典, 3:4. This may be related to the Indian Tantric use of mantras to aid in disputes; see Benoytosh Bhattacharyya, An Introduction to Buddhist Esotericism (Delhi: Motilal Banarsidass, 1980), 87. 
ing Prosperity (lucun xing 祿存星) controls the hundred demons (baigui 百鬼); the star Great Gate ( jumen xing 巨門星) controls “not corpses” or perhaps "wronged corpses" ( feishi 非尸) $; 9$ and the star Insatiable Wolf (tanlang xing 貪狼星) controls evil pneumas (eqi 惡氣). The text further tells us that the Northern Dipper as a unit controls human destiny and the hundred demons.

While it is not surprising to find the Northern Dipper invoked in this text, since it is also the subject of a variety of Buddhist texts that we have discussed above, it is interesting that the next asterism that is invoked is what is known to us primarily from Daoist texts as the Three Platforms (Santai 三臺). ${ }^{96}$ The Three Platforms refers to a collection of six stars (though our text mentions only five) that are all within the constellation Ursa Major. In Daoist texts the Three Platforms asterism is connected with the power to protect human destiny, which is precisely the role it plays in the Seven Thousand Buddhas Spirit Talismans. In addition to protecting human destiny, the five stars of Three Platforms are perceived to be capable of dispelling calamities and eliminating epidemics. The first section of the text ends by ordering all demons of chaos (luangui 亂鬼) to remove themselves to a distance of a million $l i$, and this command is enforced with the now familiar juridical injunction: "quickly, quickly in accordance with the statutes and ordinances" (jiji rulü ling 急急如律令).

The next section of the text merely introduces the names of five of the fifteen talismans that are pictured later in the text. These five talismans include: (1) Talisman for Opening the Heart/Mind (xinkai fu 心開符); (2) Talisman for Adding Years to One's Life (yisuan fu 益算符); (3) Talisman for Saving and Protecting One's Bodily Fate (jiuhu shenming fu 救 護身命符); (4) Engraved Talisman for when Metal, Wood, Water, Fire, and Earth are out of alignment (jin mu shui huo tu buxiang kefu 金木水 火土不相刻符); and (5) Spirit Talisman of the Demon of Death Aji used against Wasting (Aji sigui haoxu shenfu 阿姬死鬼秏噓身符).${ }^{97}$ This brief section ends with an injunction that commands "all evil things that see these talismans to disperse and vanish, quickly, quickly in accordance with the statutes and ordinances." 98

The central portion of this manuscript is perhaps the most interesting. It is in this section that we learn what types of benefits and powers the talismans can confer on the practitioner. These short statements are all

\footnotetext{
${ }^{95}$ I am unclear what “feshi 非尸” refers to. Mollier, "Les talismans du Buddha et de Laozi," 181, translates the term as "ghosts" (les fantômes).

${ }^{96}$ On the importance of “Santai 三臺” in Daoism, see Dōkyō jiten 道教事典 (Tokyo: Hirakawa shuppansha, 1994), 214.

${ }^{97} \mathrm{I}$ am not sure what this last name refers to.

${ }^{98}$ T. 85.1446b2-5.
} 
couched in an incantation style that has a long history in Daoist texts and later infiltrated Buddhist incantation texts. ${ }^{99}$

After putting on the talisman(s), all the Buddhas give life to me; all of the sūtras are conveyed to me; radiance shines on me; yin and yang care for me; the four seasons nourish me; the five elements [wuda 五大] guide me; five clouds cover me; bodhisattvas protect me, the six hundred cyclical signs cover me; the five emperors assist me; the five musical notes entertain me; the five troops guard me; the stars and asterisms regulate me; the five silks accompany me; the five fragrances perfume me; I recline on a golden bed and a brocade quilt covers me; transcendents support me; jade maidens attend to me; the green dragon guides me; the white tiger flanks me; governors, dukes, marquises, and commissioners receive me; the five surnames [clans] respect me; the ten-thousand surnames honor me; superiors obey me; fellow villagers are attracted to [or seduced by] me; bows and arrows, swords and soldiers, robbers and bandits are all repelled by me; tigers, wolves, and snakes all avoid me; the five poisons and gu worms are kept out of my body. ${ }^{100}$

After putting on this talisman heaven opens and all directions are passable. The hundred demons will not follow. If I fall into water I will not drown. Swords and weapons will not injure me. My comings and goings will be auspicious and good. I will not meet with calamity or misfortune. I receive protection from the troops of the four directions and five marchmounts.... Worthies will cherish and respect me. Excellent medicines will be given to me. Divine talismans will protect me. The hundred demons will avoid me. The hundred spirits will adore me. The Gate of Heaven will open for me, and the Door of Earth will exclude me. ${ }^{101}$ Cool spring water will be my drink. Wind, frost, and rain will all vanish from my way. Those who are faced with this talisman will die and those who go against [the orders of] it will perish. ${ }^{102}$

After listing the names of nine more talismans and the demons that they are responsible for repressing, this section again concludes with a forceful command that says, "[Carry out] that which has been decreed, quickly, quickly in accordance with the statutes and ordinances."103 This list of the benefits and powers available to the possessor of these talismans is a fine example of how these talismans provided both protection (including the expelling of noxious animals and demons) and assured the practitioner cer-

\footnotetext{
99 See the comments about this incantatory text in Strickmann, Chinese Magical Medicine, 107-8, which includes a slightly different translation of parts of this passage.

${ }^{100}$ On $g u$ worms as a form of demonic ailment, see Harper, Early Chinese Medical Literature, 300 n. 5, where at that early date talismans were already being used to cure people of them.

101 On “tianmen 天門” and “dihu 地戶," see Hanyu da cidian, vol. 2, 1020.

102 T. $85.1446 \mathrm{~b} 11-19$.

103 T. $85.1446 \mathrm{~b} 29-\mathrm{c} 1$.
} 
tain benefits (including riches, power, brocades, and respect). At the end of the text we are given a glimpse of the fifteen talismans whose powers are advertised in this text, and it is precisely these talismans that provided the final clue allowing us to bring together a variety of different Dunhuang fragments that can all be pieced together in order to arrive at a complete version of this text, since the beginning and end of some versions of the text had become detached and were lost.

These written talismans all appear to be a mixture of "repeated script" ( fuwen 復文) and composite graphs. ${ }^{104}$ The talismans that conclude the text are similar to contemporary Daoist talismans. Given the style of the incantation in the text along with certain other textual attributes (like the reference to the Three Platforms), some suspicions about the text's authenticity may already have been raised in the mind of the reader, as they were for some earlier scholars. Lionel Giles and Yabuki Keiki 矢吹 慶輝 both speculated that Seven Thousand Buddhas Spirit Talismans was an apocryphal work that was most likely composed or compiled in the late seventh century. ${ }^{105}$ While they were on the right track and in good company, since this is how the text was treated in classical Buddhist catalogssuch as the Catalogue of Scriptures Authorized by the Great Zhou (Dazhou kanding zhongjing mulu 大周刊定眾經目錄), dated to 695-further research reveals that the Seven Thousand Buddhas Spirit Talismans was not simply a text composed in China but has an almost verbatim copy in the Daoist canon. The Marvelous Classic Spoken by the Great Lord Lao for Extending One's Life (Taishang Laojun shuo changsheng yisuan miaojing 太上老君説長生益, 算妙經, HY 650) contains much of the same content and includes an identical set of talismans (see fig. 12). ${ }^{106}$

In the Dunhuang Buddhist version of the text, however, overtly Daoist names of deities are replaced with Buddhist names, and some sections of the complete text have been excised. Both texts end with the same list of five talismans given above, and both include a further list of ten talismans

104 See, e.g., Wang Yucheng's study of "repeated script" (fuwen) that is the style used in the Taiping jing 太平經, in “Luoyang yanguang yuannian zhushu taoguan kaoshi 洛陽延光 元年朱書陶罐考釋, Zhongyuan wenwu 中原文物 1 (1993): 71-76.

105 Giles, Descriptive Catalogue, 154; and Yabuki Keiki 矢吹慶輝, Meisha Yoin 鳴沙餘 韻 (Tokyo: Iwanami Shoten, 1933), 305-6, suggest that this text dates to the seventh century. Giles does not support this assertion, but based on Yabuki's research it seems that he based this date on two possible references to this text in the Dazhoukan dingzhong jing mulu 大周 刊定眾經目錄 (often referred to simply as Dazhou lu) catalog (where it is listed as a spurious scripture) that is dated to 695 (see T. 55.474a.20 and T. 55.474c.9). On the Dazhou lu, see Kyoko Tokuno, "The Evaluation of Indigenous Scriptures in Chinese Buddhist Bibliographical Catalogues," in Buswell, Chinese Buddhist Apocrypha.

106 See Xiao Dengfu, Daojiao shuyi yu mijiao dianji, 436ff. A clearly related text is also the Taishang Laojun shuo yisuan shenfu miaojing 太上老君説益等神符妙經 (HY 672). The best comparative study of the Buddhist and Daoist versions of these texts is provided in Masuo Shinichirō, "Nihon kodai no jufu bokukan, bokusho doki to gigi kyōten." 


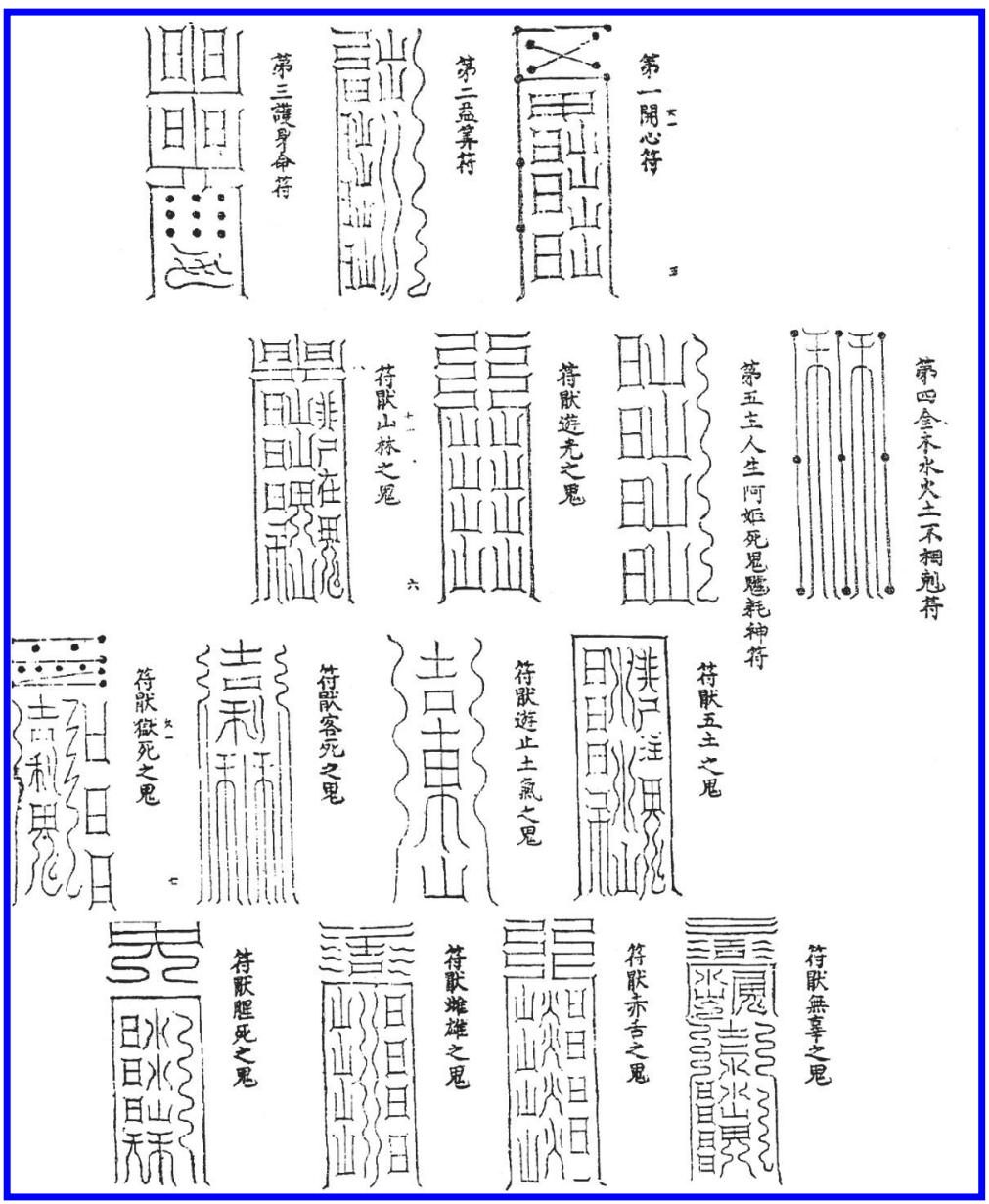

FIG. 12.-Talismans from The Marvelous Classic Spoken by the Great Lord Lao for Extending One's Life (Taishang Laojun shuo changsheng yisuan miaojing 太上老君説長生益算妙經, HY 650). Reference numbers (beginning with HY:) are to the Zhengtong Daozang 正統道藏, 60 vols. (1445; repr., Taibei: Yiwen Yinshuguan, 1962). Source: Weng Dujian 翁獨健, Daozang zimu yinde 道藏子 目引得 (Combined indexes to the authors and titles of books in two collections of Taoist literature), Harvard-Yenching Institute Sinological Index Series, no. 25 (Beijing: Yenching University, 1935; repr., Taibei: Chengwen, 1966).

with the title "fuyan" or "fuya" 符厭, which serve to "suppress" different types of demons. ${ }^{107}$ While it was initially tempting to interpret this

107 On the term "fuyan" or "fuya," see Gao Guofan, Dunhuang minsu ziliao daolun, 312; and Hanyu da cidian, vol. 8, 1125-26. 
Buddhist text as a direct copy of a Daoist original, that seemingly plausible conclusion had to be deferred due to other contextual information.

It is now generally accepted that the Dunhuang caves were "closed" by the early eleventh century, which provides us with a rather solid terminus ad quem for the Buddhist version of this text. According to Rong Xingjiang, the latest dated Chinese manuscript from Dunhuang is from 1002. He suggests that the cave was sealed soon after this date, possibly when the kingdom of Khotan to the west (with which the ruling family of Dunhuang had close ties) fell to the Islamic Karakhanids in $1006 .{ }^{108}$ We can, however, push the date for this Buddhist manuscript back much earlier with reference to Buddhist catalogs. There are three texts listed in the Catalogue of Scriptures Authorized by the Great Zhou (695) with names that are nearly identical to the Seven Thousand Buddhas Spirit Talismans. ${ }^{109}$ The names of the Buddhist versions of the text are also found beginning in the mid-eighth century in Japanese records held at the Shōsōin 正倉院, a storehouse within the Tōdaiji Temple 東大寺 in Nara where the temple's treasures are stored. ${ }^{110}$

The Daoist version of the text is not, however, attested in the corpus of Dunhuang manuscripts or in any of the catalogs of Daoist texts found in Song libraries. ${ }^{111}$ Based on internal textual evidence, it appears that the extant Daoist version of this text may postdate the eleventh century, since near the beginning of the text we find the name Wang Wenqing 王文卿 (1093-1153) listed as one of the generals of the six cyclical jia (liujia jiangjun 六甲將軍), who are empowered by Lord Lao to ward off calamities, protect people and prolong lives. ${ }^{112}$ Although Wang is presented here as a deified celestial general, he was known in his mortal existence as a famous thunder ritual master who carried on the Divine Empyrean (Shenxiao 神霄) tradition, which was based on the textual revelations of Lin Lingsu 林靈素 (1076-1120). ${ }^{13}$ The name Wang Wenqing does, however, appear in a couple of Zhengyi "register texts" that list the six jia generals, but it is difficult to arrive at a precise date for those texts. ${ }^{114}$ It

\footnotetext{
${ }^{108}$ Rong Xinjiang, "The Nature of the Dunhuang Library Cave and the Reason for Its Sealing," Cahiers d'Extreme-Asie 11 (1999-2000): 247-75.

109 T. $55.474 \mathrm{c}$.

110 Masuo Shinichirō, "Nihon kodai no jufu bokukan, bokusho doki to gigi kyōten," 92.

${ }^{111}$ See Piet van der Loon, Taoist Books in the Libraries of the Sung Period (London: Ithaca Press, 1984).

${ }^{112}$ HY 650 1b-7-8. I appreciate the assistance that Lowell Skar provided in interpreting this section of the text (personal communication, 2005).

${ }^{113}$ On Lin Lingsu and Wang Wenqing in the context of Senxiao Daoist history, see Lowell Skar, "Ritual Movements, Deity Cults and the Transformation of Daoism in Song and Yuan Times," in Kohn, Daoism Handbook, 422-24; and Davis, Society and the Supernatural in Song China, 28-30.

${ }^{114}$ See, e.g., the Protocol for the Invocation [of the Gods] of the Ten Registers of the Zhengyi Canon (Zhengyi fawen shilu zhaoyi 正一法文十籙召儀, HY 1210) and Scripture of the Officers in Charge of the Energies of the Sexagesimal Cycle, for Protecting the Embryo
} 
is possible that Wang Wenqing's name was later added to the text, but it is still noteworthy that while there are many surviving Dunhuang versions of the Buddhist Seven Thousand Buddhas Spirit Talismans, where Wang Wenqing's name is absent, there are no early extant versions of the Daoist The Marvelous Classic Spoken by the Great Lord Lao for Extending One's Life. ${ }^{115}$

Thus far I have presented a variety of Buddhist texts that include talismans that resemble those found in contemporary Daoist texts. It might be tempting to claim, as Henrik Sørensen did recently in the pages of this journal, that "talismans-whether written, printed, engraved or cast—with their highly specialized and intricate writing are unique to the Daoist tradition [and that] ... when they occur in Chinese Buddhist material, we know for certain that we are dealing with a case of direct (in the case of an unmodified talisman) or indirect (in the case of a talisman modified along Buddhist lines) borrowing from the Daoist tradition." 116 Yet I have resisted interpreting all the talismans within Buddhist texts as merely the product of a one-way borrowing. Given the evidence at hand, it would be prudent to avoid trying to assign a direction of influence on these related texts. I sympathize with Roger Chartier's suggestion that "what is needed is a historical approach not unlike that of sociologists when they try to identify cultural types not from a group of objects supposedly characteristic of a particular group but rather from the relation each group has with shared objects, knowledge, or practices." 117 The Seven Thousand Buddhas Spirit Talismans and related texts seem to be particularly good candidates for proposing that there was in all likelihood a popular template in circulation that was altered and applied to both Buddhist and Daoist ends. When it came to such significant acts, such as warding off disease demons and protecting or extending one's life, Buddhist and Daoists were occupied with the same types of concerns and employed a similar arsenal of powerful techniques that drew on the powers embedded in esoteric talismans.

and Guarding Life (Taishang shuo liujia zhifu baotai hunming miaojing 太上説六甲直符保 胎護命妙經, HY 50). HY 1210 is first attested in the Official History of the Song (Songshi 宋史 4.18b) (van der Loon, Taoist Books in the Libraries of the Sung Period, 96), but HY 50 is not attested in Song libraries.

${ }^{115}$ For dating the Daoist version of the text it may be significant that the incantatory central portion of the text, which is already found in the earliest Buddhist manuscript, is also found in other Daoist texts, but they postdate a purported new revelation of the incantation by Lord Lao in 1109. On that history see Mollier, Buddhism and Taoism Face to Face, 131-32, where, despite the late dating of the evidence, she argues for an earlier Daoist provenance.

116 Henrik H. Sørensen, "Michel Strickmann on Magical Medicine in Medieval China and Elsewhere," History of Religions 43, no. 4 (2004): 319-32.

117 Roger Chartier, "Culture as Appropriation: Popular Cultural Uses in Early Modern France," in Understanding Popular Culture: Europe from the Middle Ages to the Nineteenth Century, ed. Steven L. Kaplan (Berlin: Mouton Publishers, 1984), 234. 


\section{CONCLUSION: STRONG WORDS}

At the outset of this article I noted that throughout the ancient world there was a tendency to inscribe the language used in curse tablets and binding spells in an unintelligible, esoteric script. It is clear from the evidence presented above that there is also an abundant textual record from China detailing the long history of the use of esoteric talismans. By the Tang dynasty (at the latest), talismans and talismanic script also began to appear in Chinese Buddhist texts, where they served to repel the noxious and impel the desired. Why, however, did the compilers of the Chinese texts begin to incorporate talismans written in an esoteric Chinese script when Indian Siddham script, which was already quite popular in China due to its perceived magical properties, could have been used to the same effect? ${ }^{118}$ It seems that to the extent to which they introduced other imported esoteric powers, the compilers of these apocryphal works also drew on the perceived powers of the indigenous Chinese esoteric script. The compilers of the Buddhists texts analyzed above attempted to harness what for them must have been a powerful indigenous practice that they could add to their repertoire of potent ritual techniques.

When these types of Buddhist talismans appeared in Japan (see fig. 13) and we know that a cycle of texts surrounding the Seven Thousand Buddhas Spirit Talismans arrived in Japan during the Nara period (710-94) - it was precisely the powers they were perceived to have that worried the Nara government and eventually led to their proscription. The Rules for Buddhist Priests and Nuns (Sōniryō 僧尼令) issued in 718, for example, included an article that stipulated that "Priests and nuns who practice divination, distribute charms, perform spirit-possession, or practice medicine will, without exception, be deprived of their ordained status. Exempt from this rule is the healing of the sick by chanting dharranis in accordance with the Buddha Dharma." 119 Therefore, the oral was acceptable, while the written was proscribed. Despite this injunction, talismans with esoteric script, often coupled with Siddham script and the phrase "quickly, quickly in accordance with the statutes and ordinances" (jiji rulï ling), survived and circulated widely in Japan, where they can still be seen in use today. ${ }^{120}$

118 Robert H. van Gulik, Siddham: An Essay on the History of Sanskrit Studies in China and Japan (Delhi: Jayyed Press, 1980), 46. There is at least one example (that I am aware of) where a charm is written in Siddham, see the illustration in Weidner, Latter Days of the Law, 297-98. Siddham are also of course found on Japanese talismans, see the examples in Strickmann, Mantras et Mandarins, 367, and in Shingon mikkyō no hon 眞言密教の本 (Tokyo: Gakken, 1997), 159-60.

${ }^{119}$ Cited in Abé, The Weaving of Mantra, 162.

120 This is a vast topic, but on the use of the phrase "quickly, quickly in accordance with the statutes and ordinances" ( jiji rulü ling) in Japan on talismans with esoteric script, see the fine essay by Maeda Ryōichi 前田良一, “'Kyūkyū joritsurei’ o saguru 急急如律令, ” in Dōkyō to 


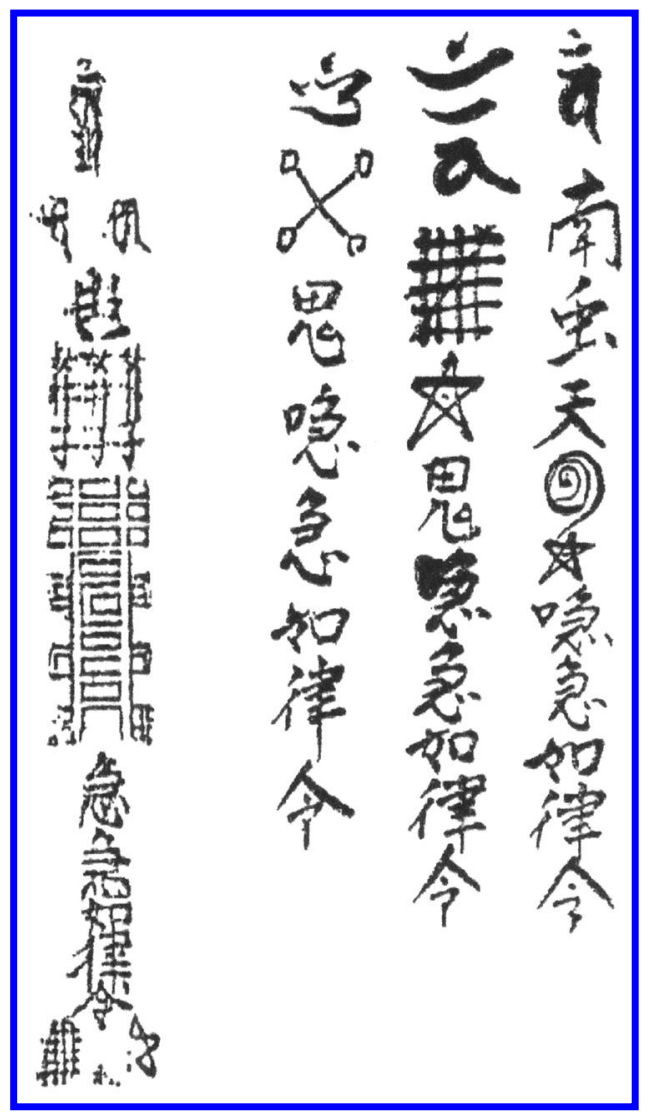

Fig. 13.-Example of Buddhist talismans from Japan with mixture of esoteric script and Siddham letters. Source: Talisman example copied from popularly circulating talismans in Japan.

Governmental proscriptions of esoteric script were not, however, limited to the ancient past. Many readers will be familiar with the controversy regarding the modern Chinese artist Xu Bing and the equally esoteric script that he invented for his work titled A Book from the Sky. ${ }^{121}$ It is clear from

Tō Ajia 道教と東アジア, ed. Fukunaga Mitsuji 福永光司 (Kyoto: Jinbun Shoin, 1989), 10125. There is a fascinating collection of Buddhist esoteric talismans in the eighteenth-century bibliophile Ōe Masasuke's Shinko sōsho 信仰叢書 (Tokyo: Kokosho kankōkai, 1915; repr., Tokyo: Yumani shoho, 1993), see esp. 354ff., 410-11, and 422ff.

${ }^{121}$ See Britta Erickson, Words without Meaning, Meaning without Words: The Art of Xu Bing (Washington, DC: Aurthur M. Sackler Gallery, 2001). It is unclear from reading Xu Bing's writings about his invented script if he was familiar with the types of script discussed in this article, but he does cite the Huainanzi passage (quoted above) about how the first 
the looks on the faces of those who attended Xu Bing's installations of books, hanging scrolls, and woodblock prints composed of invented characters that his work inspired a strange sense of wonder in the face of something that looked so familiar, but frustrated any attempts at understanding. Stanley Abe has pointed out that when A Book from the Sky was exhibited in 1989 "there was considerable perplexity over whether to read the work as a critique, or as an instantiation of Chinese culture, or as both; the debate reflected deep concerns and differences over the future direction of Chinese art." 122 One is left to wonder about the extent to which Xu Bing's exhibition of this esoteric script was also perceived to be seditious by the Chinese government, but that was precisely the way the work came to be represented abroad despite (or because of) Xu Bing's own silence on the matter. ${ }^{123}$

Talismans and esoteric script seem, however, to have presented a different kind of wonder and danger for modern scholars. Despite their ubiquity in Buddhist sources, one of the possible reasons that these esoteric talismans have remained largely undiscussed in studies of Chinese Buddhism is due to similar factors at work in the neglect of charms and talismans in the study of ancient Greece. John Gager has noted that this "persistent neglect stems surely from the potentially harmful character of these small metal tablets-not so much the real harm suffered by their ancient targets but the potential harm to the entrenched reputation of classical Greece and Rome, not to mention Judaism and Christianity, as bastions of pure philosophy and religion." ${ }^{124}$ Previously held views about a "pure" or rational Buddhism also lead to the occlusion (perhaps even systematic erasure) of Buddhist talismans in scholarly writing on Chinese Buddhism. In the process of approaching these powerful words we are not only led to acknowledge the presence of talismans within Buddhism, but we were also urged to consider the mutual interchanges and borrowings that characterized the relationship between Buddhists and Daoists- to say nothing of the impact of Chinese popular religion-in medieval China, another previously harmful topic for those concerned with guarding the sectarian walls erected between those traditions.

\section{Harvard University}

script made the demons howl at night. See, e.g., Xu Bing, "To Frighten Heaven and Earth and Make the Spirits Cry," in The Library of Babel (Tokyo: NTT InterCommunication Center, 1998).

${ }^{122}$ Stanley K. Abe, "No Questions, No Answers: China and A Book from the Sky," in boundary 2, 25, no. 3 (1998): 175. On the political context of calligraphy, see also Richard Curt Kraus, Brushes with Power: Modern Politics and the Art of Calligraphy (Berkeley: University of California Press, 1991).

${ }^{123}$ Some of the problematic issues of linking A Book from the Sky to the June 4, 1989, incident are discussed in Abe, "No Questions, No Answers," 181-82.

${ }^{124}$ Gager, Curse Tablets and Binding Spells from the Ancient World, 3. 